\title{
A new tectonic model for the Palaeoproterozoic Kautokeino Greenstone Belt, northern Norway, based on high-resolution airborne magnetic data and field structural analysis and implications for mineral potential
}

\author{
lain H.C. Henderson', Giulio Viola ${ }^{1,2}$ \& Aziz Nasuti' \\ ${ }^{1}$ Geological Survey of Norway, Pb 6315 Sluppen, 7491 Trondheim, Norway. \\ ${ }^{2}$ Department of Geology and Mineral Resources Engineering, Norwegian University of Science and Technology, Sem Seelands veg 1, 7491 Trondheim, Norway.
}

E-mail corresponding author (Iain H.C. Henderson): iain.henderson@ngu.no

\begin{abstract}
The Palaeoproterozoic Kautokeino Greenstone Belt (KkGB) is a highly tectonised metasupracrustal belt sandwiched between the gneissic Ráiseatnu Complex to the west and the metaplutonic Jergul Complex to the east. The KkGB has been interpreted as an Early Proterozoic rift basin inverted during the Svecofennian orogeny (c. 1.9-1.7 Ga). The structural framework and tectonic development of the KkGB remain poorly investigated and understood. New airborne magnetic and structural data help to unravel the belt's architecture and tectonic evolution, allowing its subdivision into two tectonic compartments. The eastern part shows NE-SW-trending, weak magnetic anomalies. The western part has pronounced NNW-SSE-trending anomalies. In the Jergul Complex, to the east of the KkGB, only relatively weak but pervasive NE-SW-trending anomalies are observed, similar to those in the eastern KkGB. These are locally deflected into NNE-SSW sets of discrete anomalies with a dextral offset. These two anomaly sets in the east are truncated by a pervasive set of NNW-SSE-trending strong anomalies in the western KkGB. The Jergul and Ráiseatnu Complexes display different aeromagnetic signatures suggesting that they are different terranes juxtaposed along the KkGB. Field structural analysis supports our interpretation of the geophysics. The eastern NE-SW-trending KkGB and the Jergul Complex contain flat-lying, west-dipping, NE-SW-trending shear zones accommodating dip-slip, top-to-the-east thrusting. The western NNW-SSE-trending KkGB is characterised by steeply dipping shear zones with both dip-slip and strike-slip kinematics. Strike-slip shear zones are predominantly sinistral, but coexisting sinistral and dextral kinematics are commonly observed together with steeply plunging lineations suggesting a degree of horizontal flattening. The NNW-SSE-trending shear zones, corresponding to the NNW-SSE-trending magnetic anomalies, form a mega-sinistral array truncating and sinistrally deflecting the earlier thrust structures. The KkGB is geometrically and kinematically similar to other Archaean-Palaeoproterozoic basement domains in northern Norway. Gold mineralisation at the Bidjovagge mine is genetically related to deformation along the NNW-SSE-trending ductile shear zone of the western KkGB.
\end{abstract}

Keywords: Kautokeino, structure, tectonics, kinematics, gold mineralisation

Received 16. September 2015 / Accepted 18. December 2015 / Published 12. February 2016

\section{Introduction}

The multiscalar geometric and kinematic complexities of orogen-scale shear zones in Archaean and Palaeoproterozoic shear belts and the evolution of their structural styles through time have attracted geologists' attention for decades (e.g., Robert \& Brown, 1986; Eisenlohr et al., 1989; McCourt \& Vearncombe, 1992; Vearncombe, 1998; Cagnard et al., 2007; Bergh et al., 2012). This mostly reflects and contributes to the still lively debate centred around whether classic tectonic models derived from Phanerozoic orogenic settings can be applied reliably through the general principle of uniformitarianism to the

Henderson, I.H.C., Viola, G. \& Nasuti, A. 2015: A new tectonic model for the Kautokeino Greenstone Belt, northern Norway, based on highresolution airborne magnetic data and field structural analysis and implications for mineral potential. Norwegian Journal of Geology 95, $339-363$. http://dx.doi.org/10.17850/njg95-3-05. 
hot, old, 'juvenile' crust or other conceptual geodynamic models must be invoked specifically for this primitive earth (e.g., Hamilton, 2011; Gerya, 2014; Roberts et al., 2015).

In any case, the validity of tectonic models for orogens of any age should always be vigorously tested with structural and kinematic analysis of field data (e.g., Ramsay, 1980; Hanmer, 1986; Simpson \& De Paor, 1993; Tavarnelli, 1997; Holdsworth et al., 2002; Jones et al., 2004; Viola et al., 2008a; Bergh et al., 2010; Scheiber et al., 2015). This is because ductile shear zones at all scales are an essential part of any orogenic belt, often accommodating strain during polyphase deformation histories (e.g., Sanderson \& Marchini, 1984; Jones \& Tanner, 1995; Tavarnelli et al., 2004). Geometric and kinematic models derived from their in depth analysis are thus of key importance and, when combined with geochronological data, place tight constraints on orogen build up and collapse processes. As such, they cannot be simply overlooked during the formulation of conceptual schemes of global applicability.

In addition, large-scale deformation zones commonly act as conduits for orogenic fluids (e.g., Gaál \& Groves, 1990; Groves \& Bennett, 1993; Groves et al., 1998; Vearncombe, 1998; Viola et al., 2006; Lahtinen et al., 2015; Vearncombe \& Zelic, 2015) with important implications for the transport and deposition of metals (Robert \& Brown, 1986; Vearncombe, 1998; Goldfarb et al., 2001). This is also the case in the Fennoscandia Shield (Gaál, 1990; Gorbatchev \& Bogdanova, 1993; Saalmann et al., 2009; Lahtinen et al., 2011; Angvik, 2014). Elucidating the geometry and tectonic evolution of these shear belts and the spatial

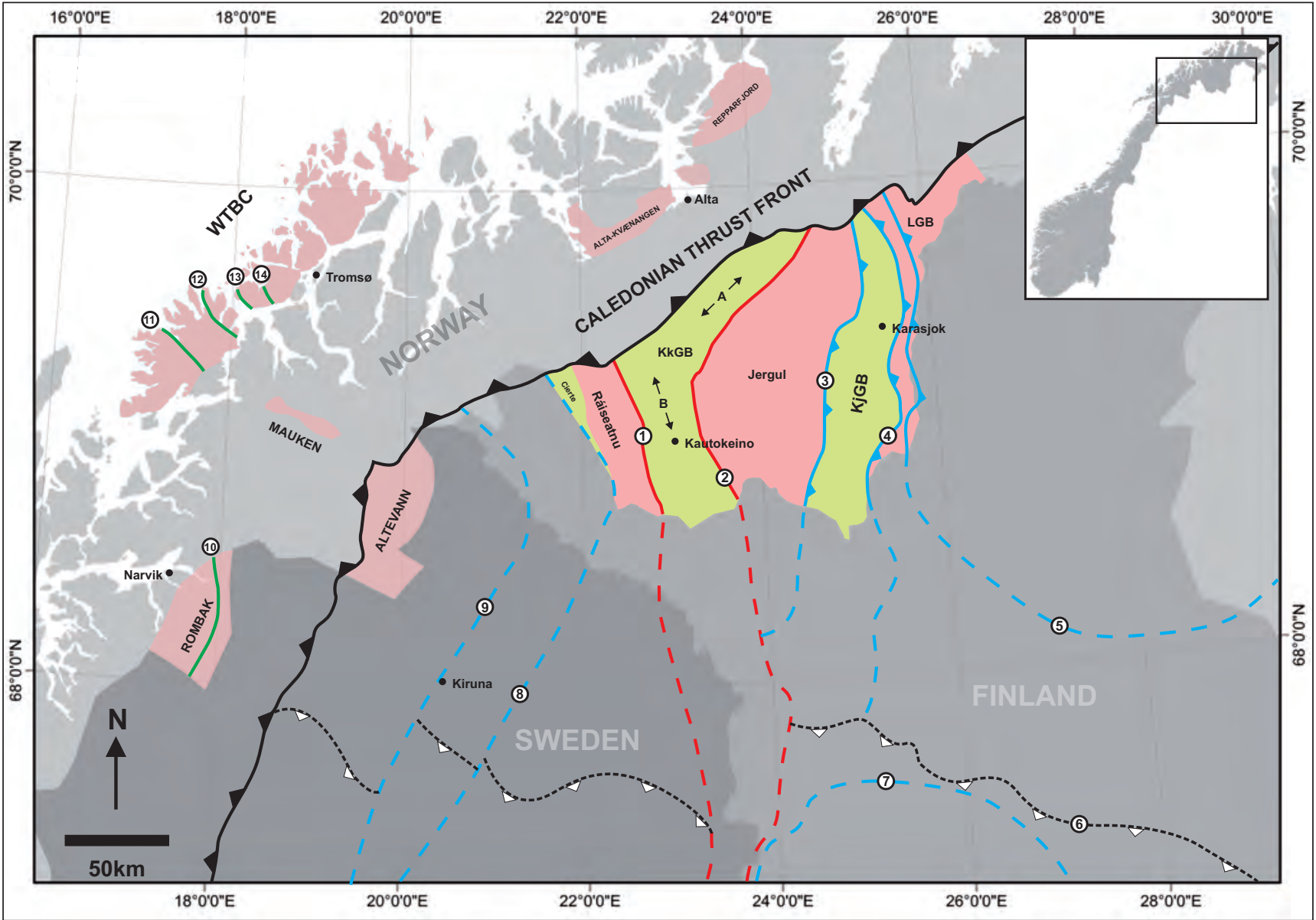

Figure 1. Regional map showing the location of the Kautokeino Greenstone Belt (KkGB) and the main structural trends of other Palaeoproterozoic and Archaean basement areas in Norway both to the west and to the east of the Caledonides. The KkGB is shown in green along with the Karasjok Greenstone Belt (KjGB). Granitic basement domains are shown in red. The Ráiseatnu Complex is to the west of the KkGB and the Jergul Complex is to the east. The Levajok Granulite Belt (LGB) is farthest east. The KkGB has a peculiar arcuate shape, forming a NE-SWtrending segment (A) in the northeast and a NNW-SSE-trending segment in the west and south (B). The possible continuation of the KkGB into Fennoscandia (Finland and Sweden) is shown by red dashed lines. The continuation of the KjGB thrust structures (Braathen \& Davidsen, 2000) southwards into Finland and other important structures in Finland and Sweden are shown as blue dashed lines. 1 - Western margin of KkGB, 2 - Eastern margin of KkGB, 3 - Western margin of Karasjok Greenstone Belt (KjGB), 4 - Eastern margin of KkGB, 5 - Western margin of Lapland Granulite Belt, 6 - Sirkka Line, 7 - Venejoki Thrust, 8 - Karesaundo-Arjeplog Shear Zone (KASZ), 9 - Kiruna-Naimakka Shear Zone (KNSZ). The important Palaeoproterozoic basement areas in Norway discussed in the text are shown in red. Green lines show the important crustal-scale shear zones described in the literature in northern Norway: 10 - Rombak-Skjomen Shear Zone, 11 - Svanfjellet Shear Zone, 12 Astridal Shear Zone, 13 - Torsnes Shear Zone, 14 - Mjelde-Skorelvvatn Shear Zone. Abbreviation: WTBC - West Troms Basement Complex. 
and temporal relationship of the mineralisation to strain localisation and time-integrated deformation histories will, therefore, ultimately lead to better and more focused prospecting models and strategies.

In this contribution we focus on the Kautokeino Greenstone Belt (KkGB) in West Finnmark, northern Norway (Fig. 1), a still poorly understood c. $40 \mathrm{~km}$-wide, NNWSSE-trending belt of Palaeoproterozoic age composed of mafic to felsic metavolcanic sequences and associated supracrustal rocks (Holmsen et al., 1957; Siedlecka et al., 1985, Olesen \& Sandstad, 1993). The age and tectonic significance of the KkGB and the adjacent Karasjok Greenstone Belt (KjGB; Often, 1985) were presented and discussed by Krill et al. (1985), who first demonstrated the presence of pervasive deformation dominated by west-directed thrusting (Krill, 1985) in the Karasjok Greenstone Belt (KjGB). While Braathen \& Davidsen (2000) later proposed a more complex evolution with up to four distinct phases of deformation in the KjGB, the documentation of even the first-order characteristics of the structural and tectonic evolution in the KkGB remains, instead, still greatly limited, partially also due to the poor outcropping of the belt. The KkGB and the KjGB are separated by the Jergul Complex, a basement dome of Archaean tonalitic gneisses and granites (Bingen et al., this volume). The KkGB is bordered by a similar gneissic dome also to the west, where the Ráiseatnu Complex crops out. Analysis of existing geological maps and databases shows that the KkGB has a remarkable geometry characterised by a knick point that causes a sharp change in the strike of its structural grain: the northeastern part of the belt has a NE-SW trend (A in Fig. 1), which bends abruptly at the knick-point to continue with a NNW-SSE orientation at almost $90^{\circ}$ to the NE branch (B in Fig. 1). The key to our understanding of the kinematic and tectonic evolution of the KkGB is the unravelling of this peculiar geometrical signature.

Olesen \& Sandstad (1993) combined both geophysical and geological data to suggest a possible tectonic history of the area, wherein the differently oriented KkGB arms were described as documenting different phases of the belt's evolution. In detail, despite the paucity of age constraints, Olesen \& Sandstad (1993) proposed a model wherein (a) the NE-SW-striking sector corresponds to the Mierujàvri-Sværholt Fault Zone (MSFZ), a diffuse, loosely defined and, as yet, undated set of structures (A in Fig. 2) and (b) the western KkGB forms instead the Bothnian-Kvænangen Fault Zone (BKFZ). The latter is defined by a structural grain that is generally more pervasive than that typical of the MSFZ and forms a distinct c. $40 \mathrm{~km}$-wide, NNW-SSE-striking zone of the KkGB (B in Fig. 2). Although the BKFZ was first recognised in the field by Holmsen et al. (1957), its tectonic significance was not fully appreciated before the work of Berthelsen \& Marker (1986). In spite of the documentation of both sinistral and dextral displacements along the BKSZ in Norway and Finland, they concluded (op. cit.) that the overall displacement is sinistral and in the region of $c$. $120 \mathrm{~km}$ based on the offset of an older structural feature, the Sirkka Line (Henderson et al., in prep.), a flat-lying north-directed thrust located in the southern continuation of the KkGB into Finland and believed to be of Late Archaean or Early Palaeoproterozoic age. The NNWSSE-striking part of the KkGB is tentatively dated at 1880 Ma from davidite in shear-related veins in the Bidjovagge gold mine (Bjørlykke et al., 1990), although no direct link between the regional structural framework, field relationships and geochronology has ever been provided. Olesen \& Sandstad (1993) documented, also based on map-scale observations, that the NE-SW-trending MSFZ appears to be truncated and displaced sinistrally by the NNWSSE-trending BKFZ. However, both of the above studies were based mostly on map relationships with limited field input and no kinematic data from the shear zones.

Here we aim to bridge this gap by integrating our interpretation of new (and reprocessed) high-resolution airborne regional geophysical data of the region with the detailed kinematic study of selected localities in order to build up a new tectonic model for the entire belt and its Svecofennian evolution. We also propose a conceptual scheme for the belt-orogenic gold mineralisation and suggest a tentative correlation with the regional structural evolution.

\section{Regional setting}

The Fennoscandian Shield, underlying most of northwest Russia, Finland, Sweden and Norway, contains some of the oldest rocks in Europe. Its constituent lithologies, mostly TTG gneisses and volcano-sedimentary rocks ranging in age from Neoarchaean to Neoproterozoic, have undergone a complex tectonic and magmatic evolution that is only recently beginning to be understood and correlated across national boundaries (e.g., Berthelsen \& Marker, 1986; Gaál \& Gorbatschev, 1987; Nironen, 1997; Koistinen et al., 2001; Korja et al., 2006; Henderson et al., in prep.). Indeed, several gallant attempts have been made at shield-scale tectonic models (e.g., Marker, 1985; Berthelsen \& Marker, 1986; Angvik, 2014; Lahtinen et al., 2014). The Palaeoproterozoic Svecofennian orogeny (c. 1.9-1.7 Ga) was the most important tectonic event to affect the northern Fennoscandian Shield and was also the last major ductile event to penetratively shape the present-day structural grain of the exposed units (Koistinen et al., 2001). The Palaeoproterozoic deformation is interpreted to result from the accretion of island arc fragments possibly during several orogenic events (e.g., Marker, 1985, Nironen, 1997; Beunk \& Page, 2001; Korja et al., 2006; Lahtinen et al., 2008; Angvik, 2014). The individual fragments accreted on to the western margin of the Archaean craton and consist of island arc and subduction-related basinal metasupracrustal rocks. Accretion and deformation occurred along a series of 


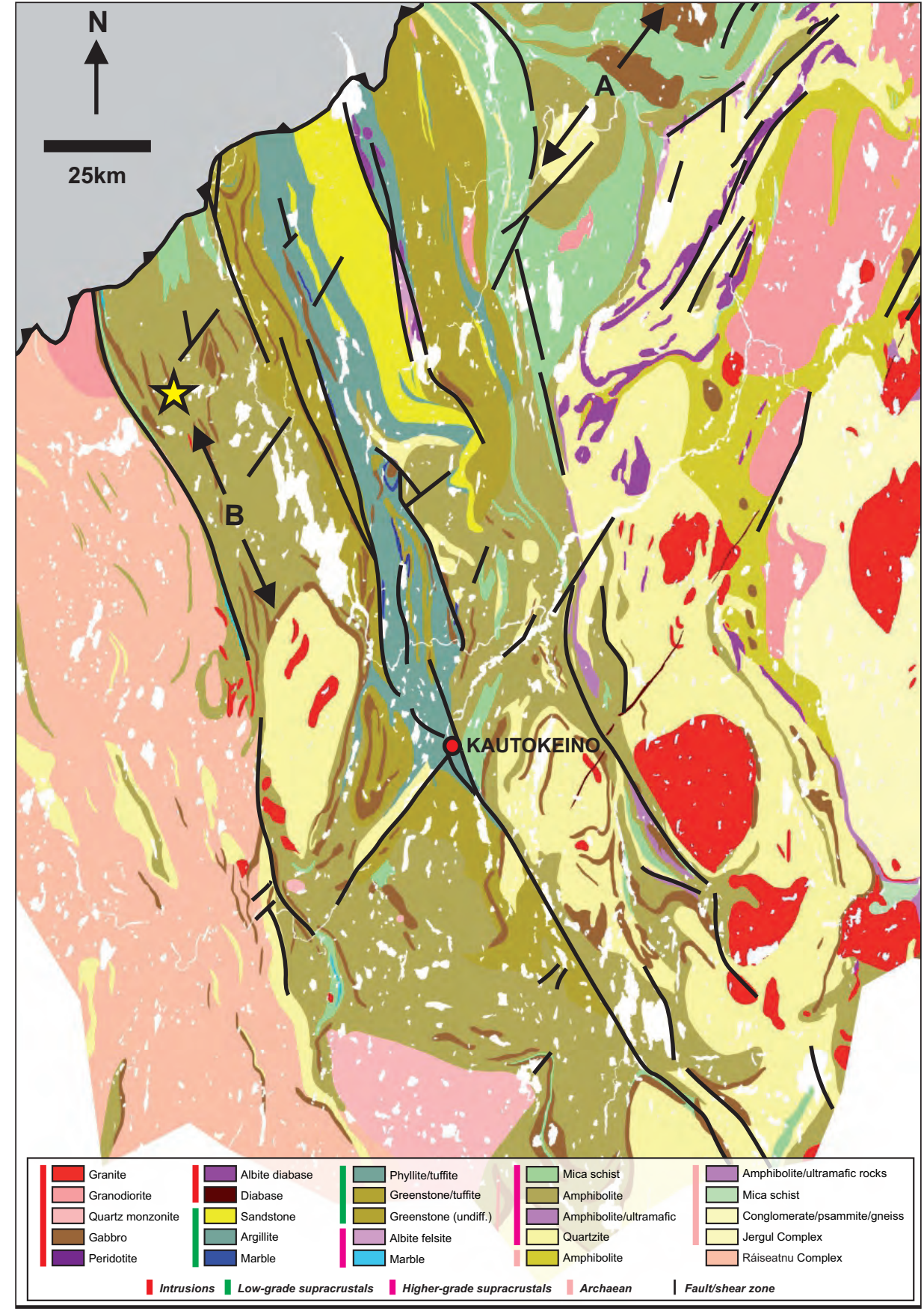

Figure 2. Bedrock map of western Finnmark (showing the main lithostratigraphic and tectonistratigraphic units). Faults and shear zones are undifferentiated (modified after Olesen \& Sandstad, 1993). Two different structural trends are observed. A NE-SW trend in the northeastern part of the KkGB (marked by A), which is parallel to the trend of the previously described Mierujàvri-Svcerholt Fault Zone (Olesen \& Sandstad, 1993), and a second oriented NNW-SSE (marked by B). The Bidjovagge gold mine is marked by a yellow star.

orogen-parallel ductile shear zones that have been studied in some detail in Norway (e.g., Marker, 1988; Armitage \& Bergh, 2005; Myhre et al., 2013; Angvik, 2014; Henderson, et al., in prep.), Sweden (Wikström et al., 1996; Bergman et al., 2006; Luth et al., 2014) and Finland (Ward et al., 1989; Saalmann et al., 2009). These ductile shear zones, like other Palaeoproterozoic shear zones around the world (e.g., Zhao et al., 2002; Goodenough et al., 2013; MacDonald \& Goodenough, 2013), acted as sites of enhanced fluid flow and, as a result, are endowed with rich mineralisations, particularly gold (e.g., Koistinen, 1981; Ward et al., 1989; Sandstad \& Nilsson, 1998; Airo \& Kurimo, 1999; Ihlen \& Furuhaug, 2000; Eilu et al., 2003; Weihed et al., 2005; Bark \& Weihed, 2007; Viola et al., 2008b; Saalmann et al., 2009; Torgersen et al., 2013; Angvik, 2014; Henderson et al., in prep.).

The description of the KkGB as a greenstone belt (Shackleton, 1995) and the first appreciation of its geological significance were by Holmsen et al. (1957). 
Siedlecka et al. (1985) established a lithostratigraphy for the entire belt and the surrounding gneissic domes of the (western) Ráiseatnu Complex and (eastern) Jergul Complex. The tectonic environment of the belt was first discussed by Torske (1977), who suggested a palaeorift setting to account for the presence of the metasupracrustal successions between the intervening granitic domes. Krill et al. (1985) provided Palaeoproterozoic geochronological constraints on the latest timing of the deposition of the rift sediments from a cross-cutting albite diabase (1815 Ma). Fareth (1979) attempted to correlate the rocks of the KkGB with other basement areas, namely the Alta-Kvænangen and Repparfjord tectonic windows (Fig. 1), west of the Caledonian thrust nappes (other attempts by, for example, Gautier et al., 1979; Torgersen et al., 2015b). However, the nature of these outlying, isolated tectonic windows northwest of the Caledonian thrust front and their relationship to the greenstone belts south of the Caledonian cover still remains poorly explored.

Olesen \& Solli (1985) were the first to explain the pervasive magnetic lineaments in the KkGB as reflecting structural features, leading only a few years later to the first bedrock digital map in Norway by Olesen \& Sandstad (1993; Fig. 2). Olesen \& Sandstad (op.cit.) in particular better characterised the geometry of the entire belt and concluded that the margins of the NNW-SSEtrending part of the greenstone belt are tectonic in nature. However, no direct link was made between the geophysical lineament patterns and the nature and kinematics of the tectonic structures as visible in the field. Torske \& Bergh (2004) studied the Čaravarri Formation, the youngest supracrustal unit in the $\mathrm{KkGB}$, and interpreted it as a molasse-type succession deposited in a growing foreland basin during progressive, west-directed thrust deformation.

With regard to the KkGB mineralisation history, Hollander (1975) and Bjørlykke et al. (1987) were among the first to publish scientific results. They focused on gold mineralisations in the northwestern part of the NNW-SSE-trending KkGB at Bidjovagge (Fig. 2) and concluded that the mineralisation was related to brecciation associated with faulting/shearing along the axial surfaces of regional anticlines. Their work, however, constrained neither the kinematics of these shear zones nor their evolution (see also later studies by Bjørlykke et al., 1990; Nilsen \& Bjørlykke, 1991; Ettner et al., 1993, 1994). Indeed, in the KkGB there is only limited documentation of the relationships between deformation and mineralisation and the timing of both is not yet constrained by isotopic dating. The only indirect dating of the shear zones affecting the KkGB was carried out by Bjørlykke et al. (1990) who dated davidite associated with gold in quartz veins associated with ductile shear zones to c. $1.88 \mathrm{Ga}$, thus constraining the gold mineralisation and presumably the formation of the shear zones to the Svecofennian orogeny.

\section{New airborne magnetic geophysical data}

\section{Methods of high-resolution aeromagnetic data acquisition and compilation}

A modern, airborne geophysical mapping of West Finnmark has recently been carried out as part of the MINN program (Mineral Resources in North Norway), a Norwegian national initiative for the better characterisation of the national territory funded by the central government and run by the Geological Survey of Norway (NGU). Older datasets have been significantly improved and a much larger area than ever before in northern Norway is now covered at high resolution. The surface extent of the new geophysical surveys covers most of northern Norway, extending from West Finnmark to the coastline of the counties of Troms and Finnmark up to approximately $71^{\circ}$ north.

Airborne magnetic data are becoming more commonly used on a regional scale for the delineation of regional structures (for example basins, basement highs, regional faults and shear zones, foliation or fabric traces) during various stages of geological investigations (Hinze et al., 2013). In Finnmark, aeromagnetic data in particular have already been applied in investigating the geological structures of West Finnmark (Olesen \& Solli, 1985; Olesen et al., 1990, 1992; Olesen \& Sandstad, 1993). However, because of diurnal artefacts, navigation errors and poor resolution of some of the vintage magnetic data acquired in the 1970s and 1980s, the up until recently available magnetic dataset (Olesen et al., 2010) was of relatively low quality and not entirely reliable for accurate qualitative and quantitative interpretation. It was therefore decided to acquire new, state-of-the-art, highresolution aeromagnetic data over the entire area of West Finnmark in order to update and replace the vintage magnetic dataset (Fig. 3). The new surveys were acquired during the summers of 2011, 2012 and 2014. These are the new FRAS and TROFI surveys (Novatem, 2014; EON Geosciences Inc., 2015). In addition, the study area includes a part of a helicopter survey, which was carried out by NGU in the Alta-Kvænangen area (Rodionov et al., 2012).

The relatively high number of tie-lines was required for the large diurnal variations in such high-latitude areas and were therefore acquired to ensure proper processing and levelling of the data. The raw data have been processed using both statistical and micro-levelling methods (using the Oasis Montaj software) and have considered base station corrections. $91,210 \mathrm{~km}$ of new aeromagnetic profiles were originally acquired by NOVATEM airborne geophysics (NOVATEM, 2012, 2014) and EON Geosciences (EON Geosciences Inc., 2015) on behalf of the Geological Survey of Norway (NGU). The final compilation with pre-existing magnetic surveys, re-processed 


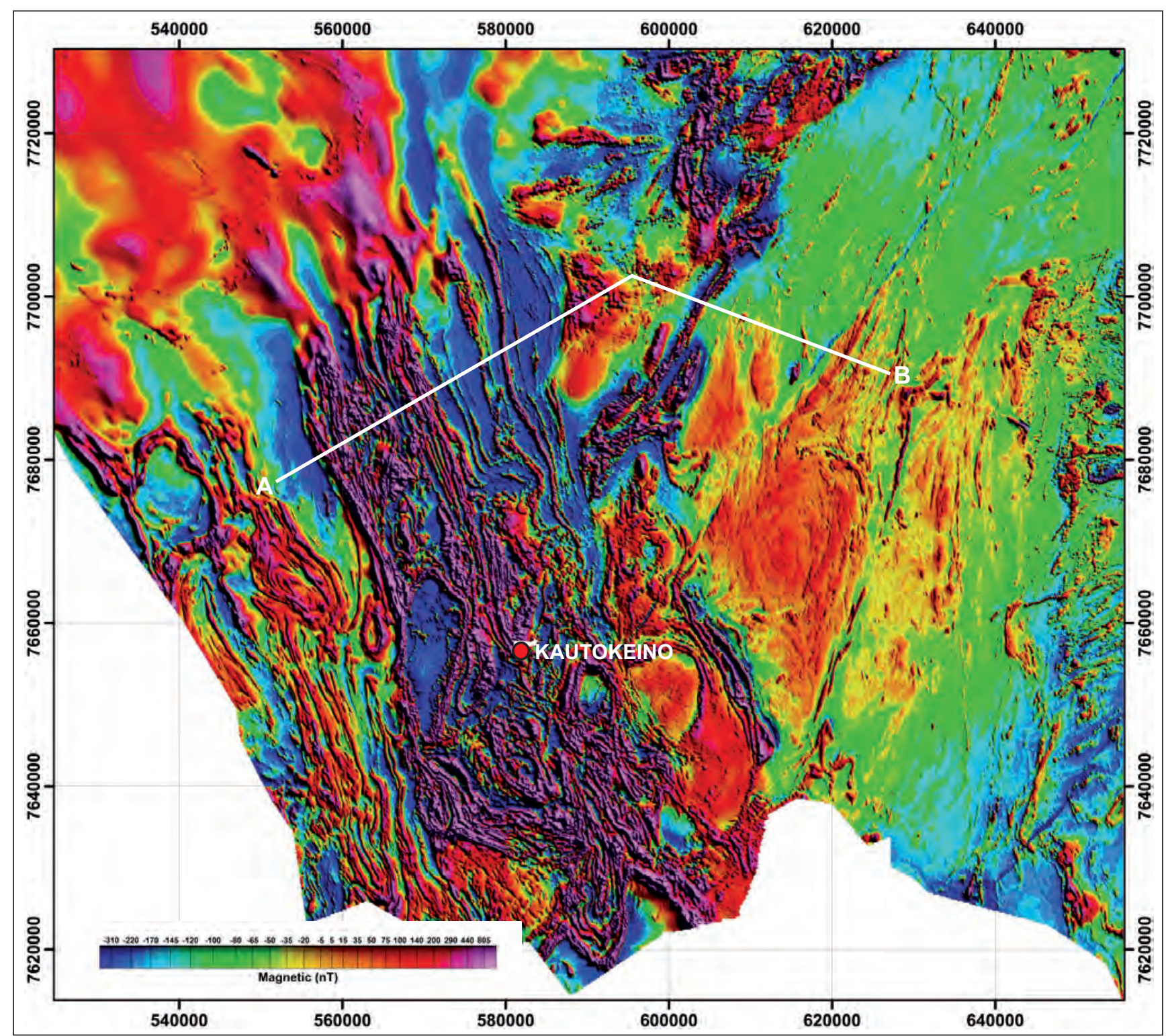

Figure 3. Compiled high-resolution aeromagnetic data (total magnetic field) for the KkGB, Jergul and Ráiseatnu complexes (see also Nasuti et al., 2015). The section A-B refers to a gravity study carried out by Olesen \& Sandstad (1993), whose results are illustrated in Fig. 13.

NGU's Kautokeino Surveys 1979-91 and Karasjok aeromagnetic surveys (Geological Survey of Finland technical report, 2007, 2008, 2009), has been carried out at NGU (Fig. 3). The technical details of this are discussed in Nasuti et al. (2015).

A number of filters and image enhancement procedures have been subsequently calculated from the magnetic total field to enhance specific magnetic trends and anomalies. Filtering and derivative calculations, especially the normalised tilt-derivative filtering (TDR; Miller \& Singh, 1994; Verduzco et al., 2004), helped to define different basement domains, sub-vertical geological boundaries, faults and dykes that are discussed in this paper (Fig. 4). The TDR filter increased the amplitude of the magnetic total field anomalies and provided an effective alternative to the vertical derivative to map the continuity of the dykes that crop out only very locally in the area.

Analysis and interpretation of the new geophysical data

In our analysis of the new geophysical data we have followed the methodological approach of Henkel (1991). The presence of tectonic/structural discontinuities, both brittle and ductile, is postulated (until confirmation by later ground truthing) when a linear discordance or set of discordances disturb or disrupt the anomaly pattern with a clear displacement or truncation, or when an obvi- 


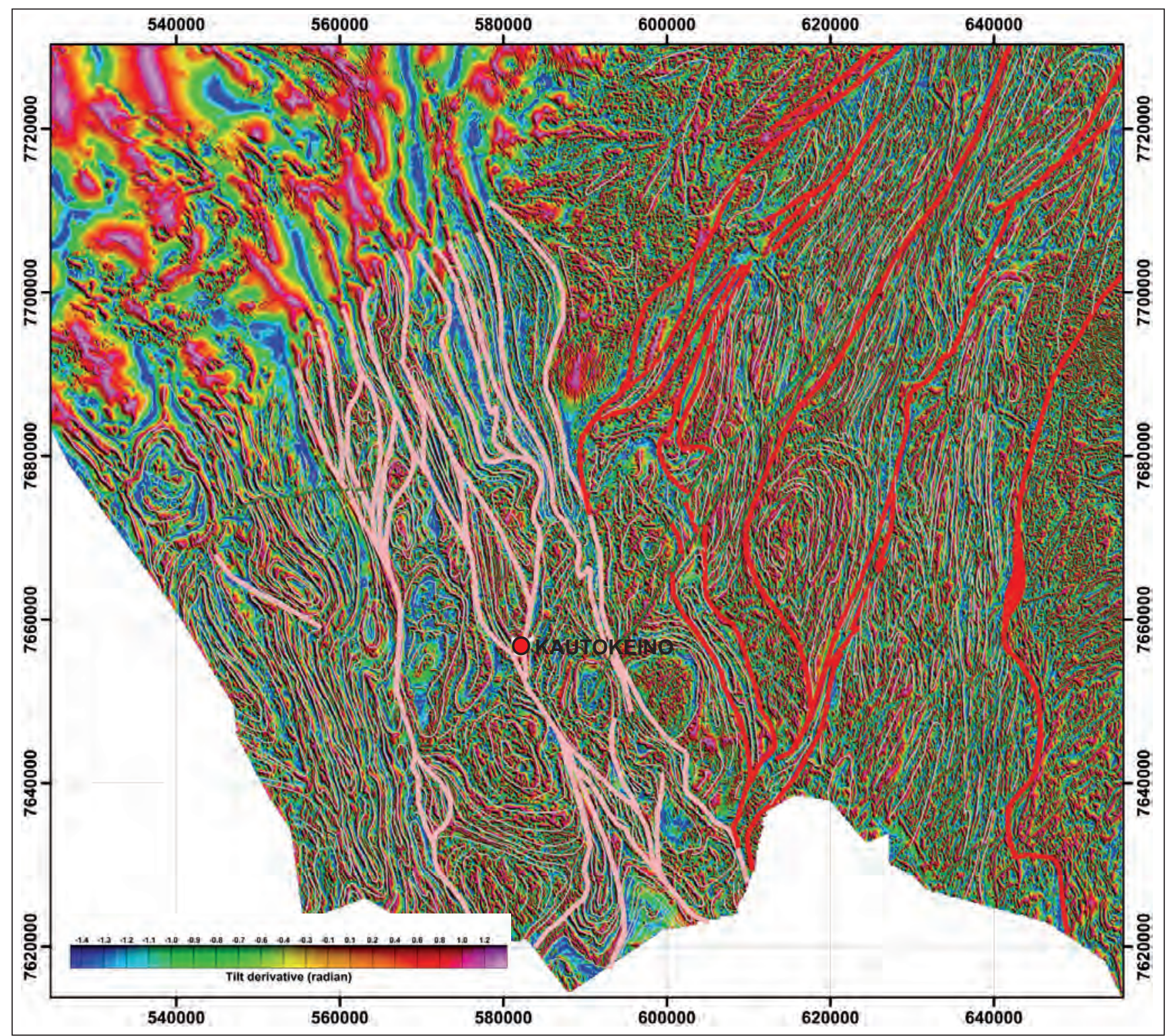

Figure 4. Compiled high-resolution aeromagnetic data (tilt derivative) showing our interpretation of the main anomalies interpreted to represent ductile shear zones (see also Fig. 5). Red lines represent dextral NE-SW-trending shear zones within the NE-SW-trending part of the $K k G B$ and in the Jergul Complex. These display an S-C geometry suggesting a component of dextral shear in map view and are deflected and locally truncated by the younger sinistral ductile shear zone of the NNW-SSE part of the KkGB (pink lines). Form lines are shown by thin white lines.

ous displacement of a reference structure is observed. By following this approach, we were able to identify both apparent brittle and ductile structural features within the KkGB aeromagnetic dataset. Ductile structures cause a progressive displacement of the affected anomalies, leading to their asymptotic deflection into the trend of the interpreted ductile shear zone. Brittle structures, instead, truncate abruptly the anomalies they intersect.

Throughout the KkGB, the new geophysical data (Figs. $3,4)$ show remarkable anomalies and linked features that may indeed represent structural fabrics, likely high-strain ductile shear zones (Figs. 4, 5).

According to our analysis, which was carried out also with reference to the pre-existing knowledge of the bedrock geology (Fig. 2), it is possible to define several separate structural domains within the airborne magnetic survey of West Finnmark, each with distinctive geophysical signatures. From east to west these domains are: (1) The Levajok Granulite Belt (LGB) which is thrust top-towest over the Karasjok Greenstone Belt (Krill et al., 1985). This domain will not be discussed further here. (2) The Jergul Complex which trends NE-SW. (3) The eastern KkGB, which trends NE-SW, parallel to the Jergul Complex, and is generally characterised by weaker anomalies than (4) the western KkGB, which trends NNW-SSE and has a very pronounced signature with magnetic anomalies up to $300 \mathrm{nT}$. (5) The Ráiseatnu Complex to the west of the western KkGB, characterised by magnetic anoma- 


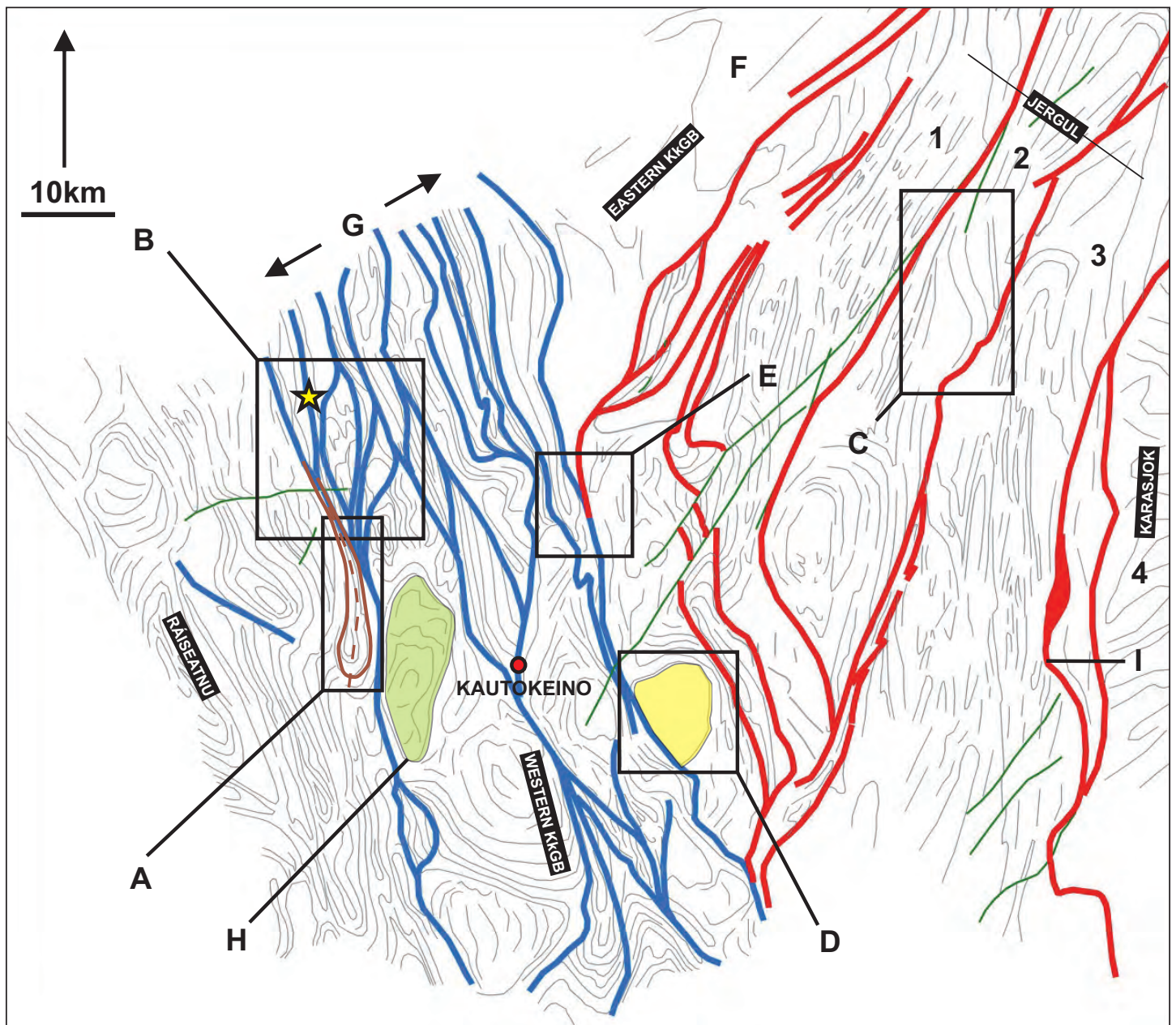

Figure 5. Line drawing interpretation of the geophysical data presented in Fig. 3 with selected highlighted areas and observations discussed in the text. Dextral NE-SW-trending shear zones in red and sinistral NNW-SSE shear zone array in blue. Form lines in light grey show the interpreted foliation trace. The location of the Bidjovagge gold deposit is marked by a yellow star. A - Isoclinal folds in the Ráiseatnu Complex that are deflected into the sinistral shear array, B - Duplex structures in the NNW-SSE-trending ductile shear zone array, C - Both pervasive (N-S striking) and discrete anomalies in the Jergul Complex suggesting ductile dextral displacement, D-An oval-shaped body, that may be an intrusion, truncated by the NNW-SSE-trending sinistral shear-zone array, E-The NE-SW-trending shear zones with a dextral component in the Jergul Complex are truncated and deflected sinistrally into the NNW-SSE-trending shear-zone array, F-The flat-lying, NE-SW-trending eastern part of the KkGB, G - The NNW-SSE-trending, $40 \mathrm{~km}$-wide sinistral shear zone array, $H$ - Asymmetric sinistral mega-clast in the NNW-SSE-trending shear-zone array, I - KjGB frontal thrust. Fabric east of this line is discordant with the NE-SW-trending Jergul fabric. Numbers 1-4 refer to different tectonic compartments in both the Jergul and the KjGB. See main text for discussion.

lies trending NNW-SSE. (6) The Cierte Greenstone Belt, which is also NNW-SSE trending and on the border between Norway and Finland. The Cierte Greenstone Belt is not discussed further here.

In the following, we will describe in more detail the magnetic anomaly patterns and structural architectures of the Jergul and Ráiseatnu Complexes (Fig. 1) to the east and west of the KkGB, respectively (Fig. 1), which display truly interesting magnetic signatures.

The Jergul Complex

In the Jergul Complex, two apparent sets of distinct anomalies are observed (Figs. 4, 5). One set is indeed pervasive throughout the Jergul Complex and is oriented generally from NE-SW to NNE-SSW (thin grey lines) but displays a different orientation in different NE-SWoriented domains (1, 2 and 3 in Fig. 5). For example, in domain 1, the anomalies are planar and NW-SE trending. In Domain 2 the anomalies are somewhat sigmoidal but generally $\mathrm{N}-\mathrm{S}$ or NNE-SSW trending. In Domain 3 , the anomalies are planar and generally $\mathrm{N}-\mathrm{S}$ trending. These anomalies are parallel to metamorphic foliation planes inferred from pre-existing bedrock maps (Fig. 2). This pervasive anomaly set is locally deflected and cut by NE-SW discontinuities (red lines in Figs. 4, 5) with an apparent component of dextral strike-slip in map view (e.g., area C in Fig. 5). The NE-SW foliation in Domain 3 in the Jergul Complex is juxtaposed against an E-Wtrending pervasive foliation in the Karasjok Greenstone Belt (KjGB; Fig. 1 and east of I in Fig. 5). 


\section{The eastern KkGB}

The eastern KkGB (Fig. 2) forms a NE-SW-trending zone bounded by the Jergul Complex to the southeast, the Caledonian thrust nappes to the northwest and the western KkGB to the west (Fig. 2). The eastern KkGB consists of mica schist, fine-grained amphibolite and local albite felsite (Suoluvuopmi Formation; Solli, 1983). Although lithologically different from the Jergul Complex (mostly felsic gneiss), the eastern KkGB magnetic signature is similar and the magnetic trend is parallel to the Jergul Complex (Figs. 3, 4). The eastern KkGB is generally a zone of quiet magnetic signature with low anomaly magnitude, long wavelength and only a small number of anomalies (Fig. 3 and F in Fig. 5).

\section{The western KkGB}

The western KkGB is defined by an approximately 40 $\mathrm{km}$-wide domain with a very high frequency of anomalies and a high density of very low-wavelength anomalies. The western KkGB is fundamentally different from the eastern KkGB, even though their mostly supracrustal rock types are similar. The western $\mathrm{KkGB}$ is characterised by NNW-SSE-trending magnetic anomalies that are almost perpendicular to the NE-SW trend of the eastern KkGB. In detail, the eastern KkGB NE-SW anomalies are deflected sinistrally into the NNW-SSE trend of the western KkGB (e.g., area E in Fig. 5) but are locally also truncated by it. An obvious example is shown in area D (Fig. 5), where an oval magnetic feature that may be interpreted as an intrusive body is truncated. The southwestern part is not visible within the KkGB, even far into the continuation of the KkGB into Finland, suggesting considerable lateral (and also vertical) displacement. Both the eastern and the western boundaries of the western KkGB are sharply defined against the lower intensity and higher wavelength of the anomalies of particularly the eastern KkGB domain and the Jergul Complex in the east but also the Ráiseatnu Complex in the west. In addition, the western $\mathrm{KkGB}$ magnetic pattern may suggest the presence of large, tight to isoclinal folds (A in Fig. 5), which are not seen or reported in either the eastern KkGB or in the Jergul Complex (Fig. 3). Within the western KkGB domain we also observe a remarkable occurrence of second-order, NNW-SSE discontinuities. Many of these seem to define duplex geometries relative to the sharp margins of the belt and have a N-S orientation, rotated clockwise from the main NNW-SSE trend. These possess a geometrical pattern that suggests a sinistral shear zone array (B in Fig. 5).

\section{The Ráiseatnu Complex}

The Ráiseatnu Complex to the west of the KkGB (Fig. 1) has an overall NNW-SSE magnetic fabric (Fig. 3 and grey lines in Fig. 5), which is parallel to the interpreted regional foliation (Fig. 2) and also to the NNW-SSEtrending western KkGB ( $G$ in Fig. 5). Although the rock types in the Ráiseatnu Complex are similar to those in the Jergul Complex (granitic gneiss and granitoids), the Ráiseatnu Complex displays a fundamentally different geophysical signature (see Fig. 3). In addition to the difference in the orientation of the anomalies, the Ráiseatnu Complex is more similar to the KkGB in terms of the higher number of anomalies, their short wavelength and their magnitude (approximately $300 \mathrm{nT}$ ) compared to the Jergul Complex. The magnetic signature in the Jergul Complex is much more subdued, with a smoother pattern, longer wavelength and generally smaller anomalies. In addition, in the Ráiseatnu Complex we did not find evidence of apparent dextral shearing as is instead the case in the Jergul Complex (C in Fig. 5). Isoclinally folded anomalies, although also present in the Jergul Complex, are much more common and more tightly folded in the Ráiseatnu Complex (e.g., A in Fig. 5). This may suggest that the Jergul and Ráiseatnu Complexes have undergone fundamentally different structural evolutions, a point of discussion elaborated below.

\section{Field observations and structural analysis}

West Finnmark is covered by a thick layer of moraine and till and outcrops are generally sparse and usually only flat pavements are visible, thus preventing access to the third dimension and good quality observations. Field structural work was therefore carried out only after the new geophysical data compilation and its preliminary tectonic interpretation. We have targeted specifically outcrops where the geophysical interpretation of Fig. 5 suggests the presence of ductile shear zones. Pre-existing exposure maps were used in conjunction with the new aeromagnetic data to select critical areas for structural work. In total, 104 outcrops were examined. Out of these, approximately 50 provided meaningful structural and kinematic data. In general, field structural observations support the geophysical interpretation presented above.

\section{NE-SW-trending structural domains of the eastern KkGB and Jergul Complex}

Fig. 6A shows foliation data for the NE-SW-trending part of the KkGB and the Jergul Complex. We have no direct constraints on the age of these fabrics. The main foliation generally strikes NE-SW and dips at a very gentle to moderate angle to the NW or SE but with much dispersion. Fig. 6B shows the limited amount of stretching lineation data for the same area. Two weak clusters of lineation orientations are observed, forming on both the east and west moderately dipping foliation, thus constraining a dip-slip thrust movement to the WSW and thrusting towards the east. These dip-slip structures broadly correspond with the NE-SW-oriented structures discussed above and that have been described as characterised by a component of dextral shear in map view (Fig. 5; in red). Based on geometric relationships seen in the geophysical data (Figs. 3, 4), we interpret them as the earliest formed ductile structures in the area. 
Fig. 6C shows the outcrop-scale fold data collected in this domain. The folds are generally open, upright and have hinges shallowly plunging towards the south, with axes almost parallel to the trend of the zone and parallel to the strike of the thrusts. In the field, a number of key outcrops (Fig. 7) show that the thrust structures form generally flat-lying features with a double vergence both to the west (in the west) and to the east (in the east) with asymmetric sigma clasts (Fig. 7A-C), verging folds (Fig. 7D), and in thin-section an extensional crenulation cleavage (Fig. 7E) and asymmetric porphyroclasts (Fig. 7F) indicating thrusting. All of the observed thrust structures appear to have formed exclusively at upper greenschist/amphibolites-facies metamorphic conditions, with, for example, stable biotite and amphibole in the more mafic lithologies defining the main thrust-related foliation (see Fig. 7F).

\section{NNW-SSE-trending structural domains of the western KkGB}

The strong magnetic anomalies that characterise the NNW-SSE structural domain of the western KkGB correspond in the field to high-strain ductile shear zones. Unlike the NE-SW-trending part of the KkGB, the structures in the NNW-SSE-trending part of the KkGB are steeply dipping (Fig. 8). Fig. 6D-F show the orientation data for the NNW-SSE-trending part of the KkGB. The foliation strikes generally NNW-SSE and dips steeply both to the WSW and to the ENE. Fig. 6E shows the limited amount of stretching lineation data collected from this structural domain. Lineations are generally dispersed but tend to cluster about a $c$. N-S axis sub-parallel to the strike of the foliation but with a small, clockwise-rotated, angular mismatch. Both steep and gently-plunging

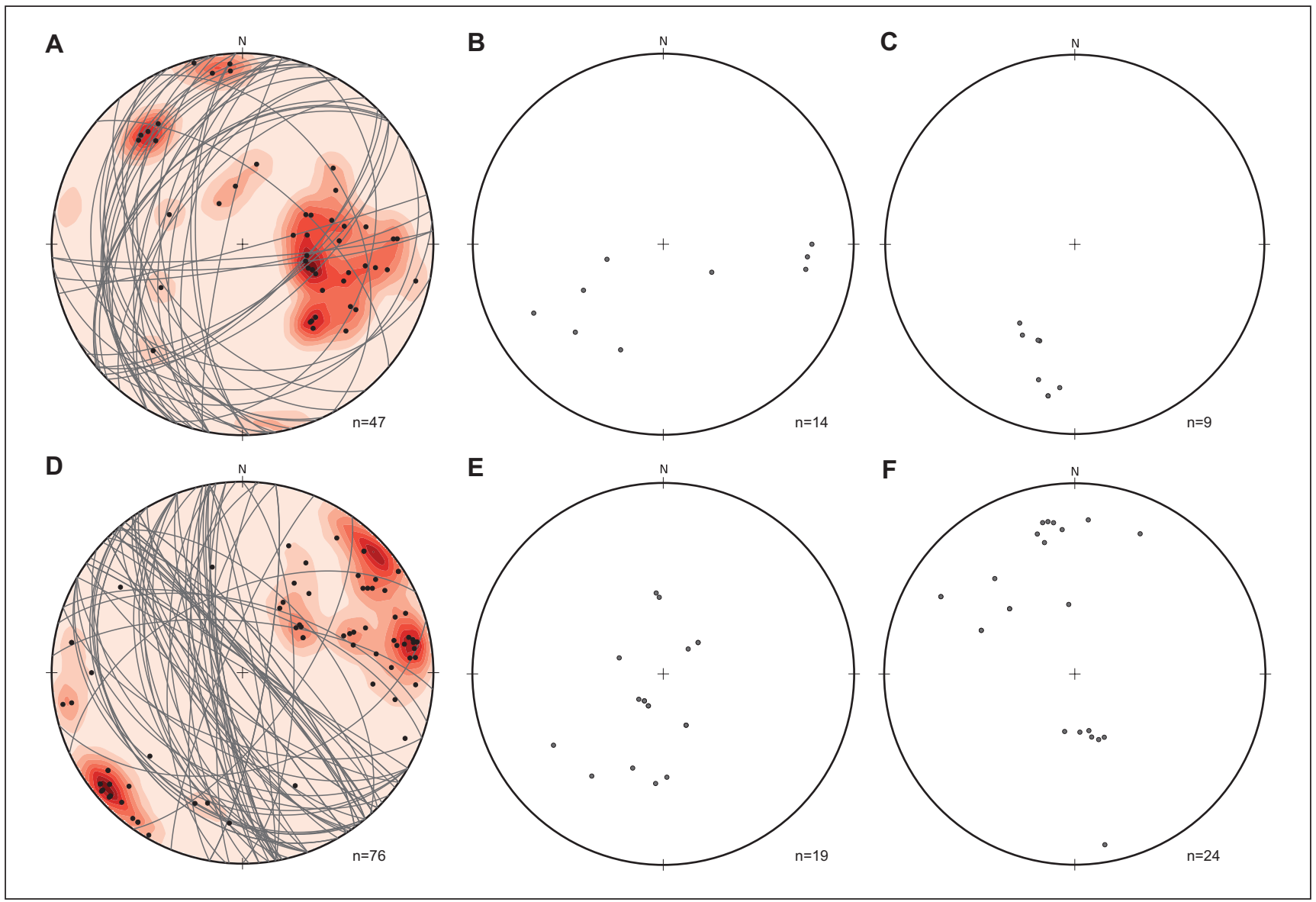

Figure 6. Structural data plotted in lower-hemisphere Schmidt stereonet for the NE-SW and NNW-SSE domains of the KkGB. (A) Foliation data for the NE-SW-trending part of the KkGB (great circles and poles) and contoured poles (in red). This domain shows a large dispersion in the foliation but a generally NE-SW strike trend (parallel to the domain) with both shallowly NW-and SE-dipping foliation. (B) Stretching lineations for the NE-SW-trending part of the KkGB. These show two gently plunging trends. One set plunges east and occurs in the western part of the belt. A second set plunges west on flat-lying, west-dipping structures in the east. (C) Small-fold axes from the NE-SW-trending part of the KkGB. These are more shallowly plunging than those in the NNW-SSE part of the KkGB and align on a NNE-SSW axis, sub-parallel to the flat-lying, thrust-related open folds in this domain. (D) All foliation data for the NNW-SSE part of the KkGB (great circles and poles) and contoured poles (in red). (E) Stretching lineations for the NNW-SSE part of the KkGB. The stretching lineations, like the foliation, show a large dispersion but are generally steeply plunging, representing the overall dip-slip oblique transpressional deformation. (F) Small-fold axes from the NNW-SSE-trending part of the KkGB. They display a similar NNW-SSE axial trend. Some steeply plunging small folds are related to a pure strike-slip movement on the gold-bearing structures in the Bidjovagge deposit. 

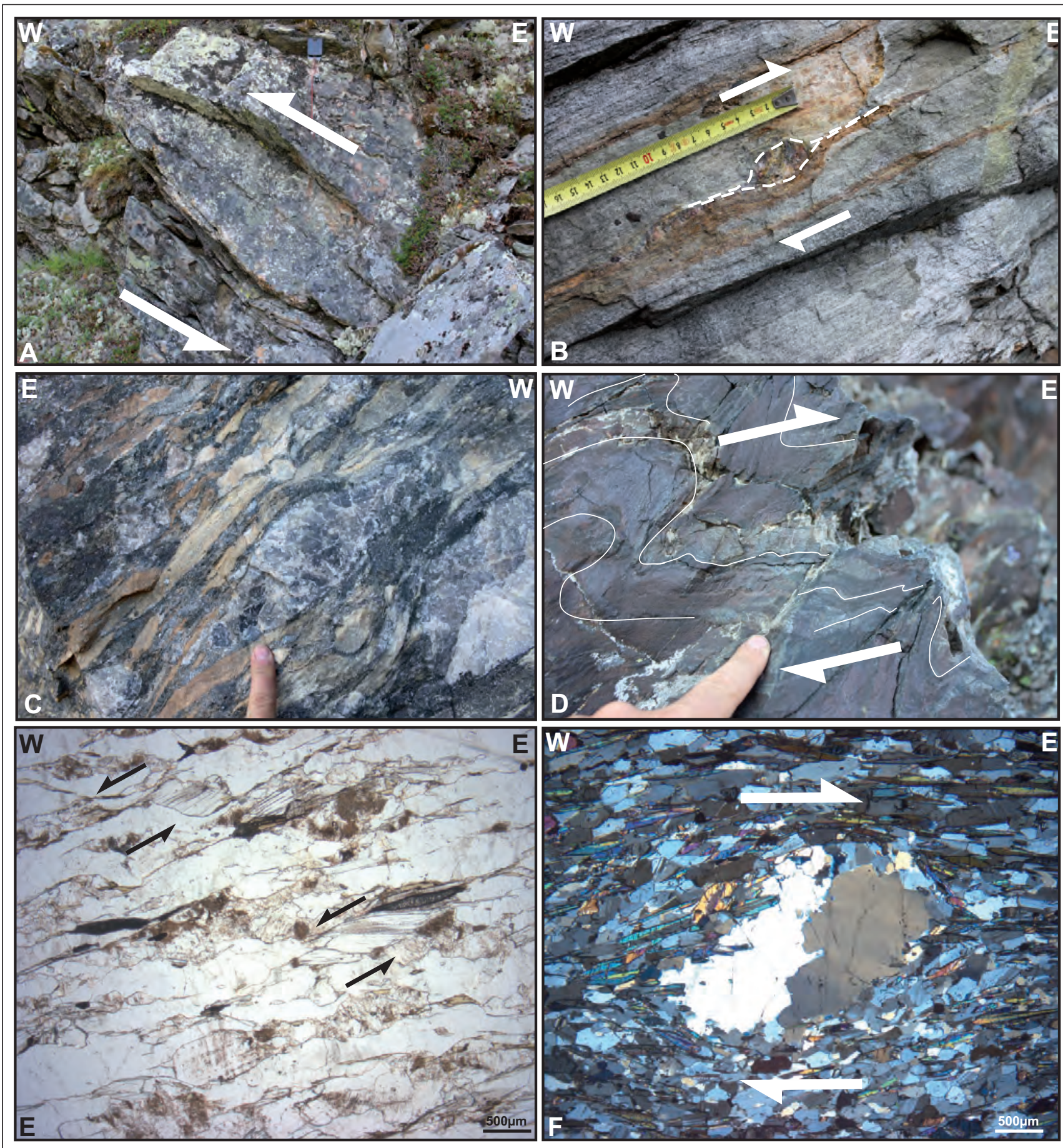

Figure 7. Examples of kinematic indicators from early dip-slip thrust shear zones. (A) Outcrop scale asymmetric clast showing top-to-the-west kinematics in the western part of the NNW-SSE-trending part of the KkGB. (B) Top-to-the-east asymmetric porphyroclasts in the eastern part of the KkGB. (C) Asymmetric conglomerate clast in the Čaravarri Formation in Kautokeino town centre. (D) Asymmetric east-verging folds in flat-lying, west-dipping sedimentary rocks associated with top-to-east thrusting. (E) Photomicrograph showing extensional crenulation cleavage indicating top-to-west thrusting at locality 85 (see Figs. 5, 6). See corresponding mesoscale structures in Fig. 7A. (F) Photomicrograph showing top-to-east, dip-slip thrusting structure from locality 89 from the eastern margin of the KkGB (see Figs. 5, 6) Abundant syn-kinematic hornblendes are visible in the shear zone foliation suggesting development at amphibolite-facies metamorphic grade.

lineations are present and these will be discussed below in detail. Fig. $6 \mathrm{~F}$ shows the orientation of mesoscopic fold axes for the NNW-SSE part of the KkGB. These folds deform the mylonitic foliation that developed during the formation of the NNW-SSE-trending structures. The folds trend generally $\mathrm{N}-\mathrm{S}$ with a tendency towards the
NNW-SSE, parallel to the main sinistral shear zone array that can be interpreted for this area from the available geophysics (Figs. 4, 5). There is also a significant dispersion of the fold axis data along an approximate $\mathrm{N}-\mathrm{S}$ axis, with both steeply and shallowly plunging folds. 

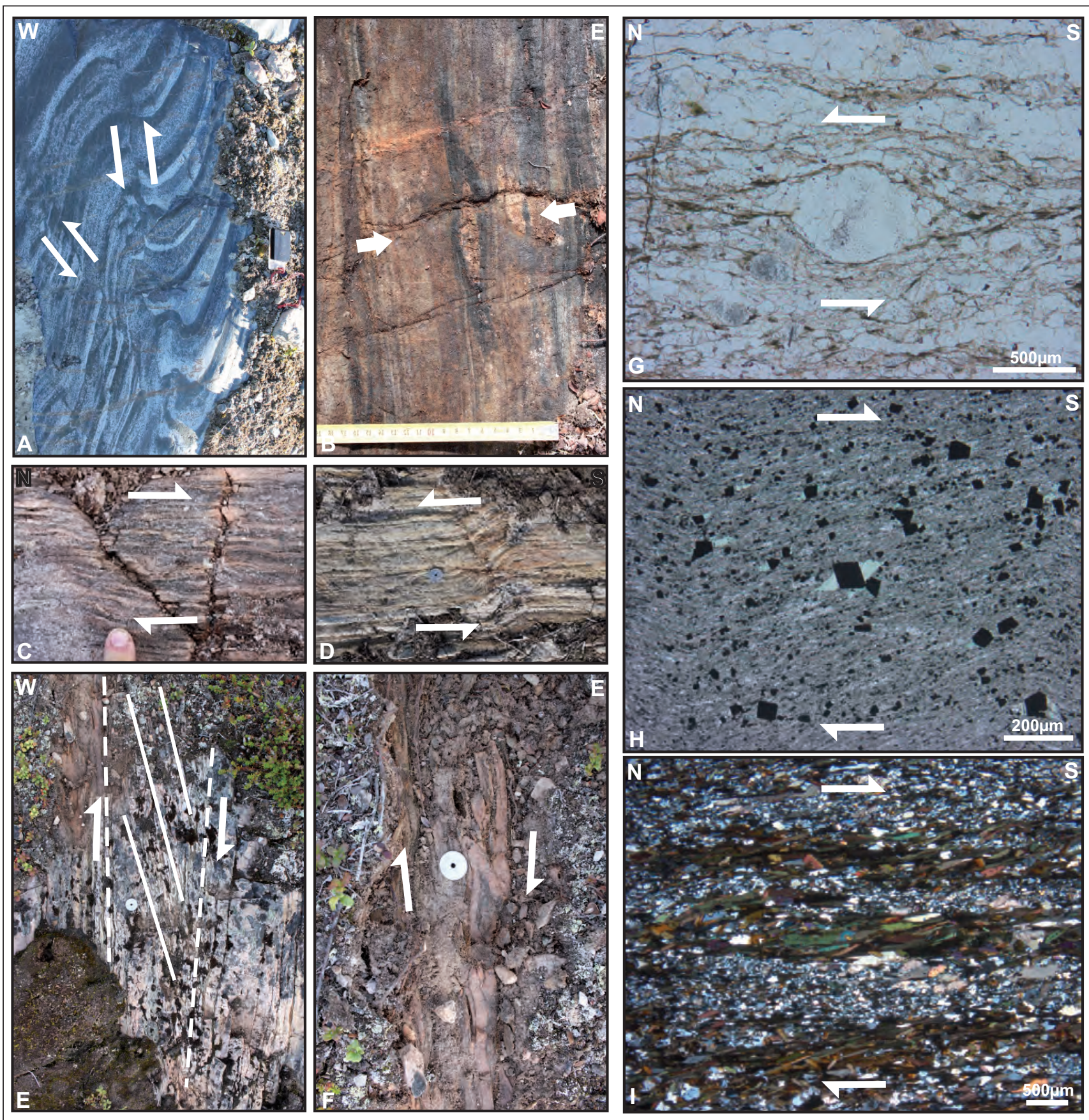

Figure 8. Examples of kinematic indicators from the NNW-SSE-trending western KkGB. (A) Sinistral shear zones in amphibolitic banded schist near the Bidjovagge gold deposit. (B) Symmetric porphyroclasts in metasupracrustals suggesting pure-shear contraction. (C) Dextral drag folds with steep fold axes in pre-existing, $N-S$, steep mylonitic fabric associated with the sinistral NNW-SSE-trending shear-zone array. (D) Sinistral drag folds with steep fold axes in pre-existing, N-S, steep mylonitic fabric associated with the sinistral NNW-SSE-trending shear-zone array. (E) Proto S-C fabric in metasupracrustals. (F) Dextral, isoclinal drag folds in pre-existing, N-S, steep mylonitic fabric associated with the sinistral NNW-SSE-trending shear-zone array. (G) Sinistral (strike-slip) quartz sigma clast from locality 36. (H) Dextral asymmetric chlorite pressure shadows on pyrite grains in a steep ductile shear zone (locality 70) suggesting shear zone development at greenschist facies. The horizontal in the photo is approximately parallel to the shear plane in an otherwise moderately crenulated foliation. (I) Dextral asymmetric mica fish in a steep ductile shear zone at locality 18.

Both sinistral (Fig. 8A, D) and dextral (Fig. 8C, E, F) strike-slip kinematics are observed along the NNWSSE-trending shear zones. Some outcrops, however, lack clear asymmetries, with abundant symmetric porphyroclasts within the shear foliation, which may suggest a flattening component across these steep shear zones. The geological processes possibly responsible for this will be discussed below. Sinistral (Fig. 8D) and dextral (Fig. 8H, I) kinematic indicators (such as asymmetric porphyroclasts, extensional crenulation cleavage and asymmetric mica fish; Passchier \& Trouw, 1996) are also commonly observed on the microscale. Whereas many of these steep shear zones appear to have accommodated strain under 


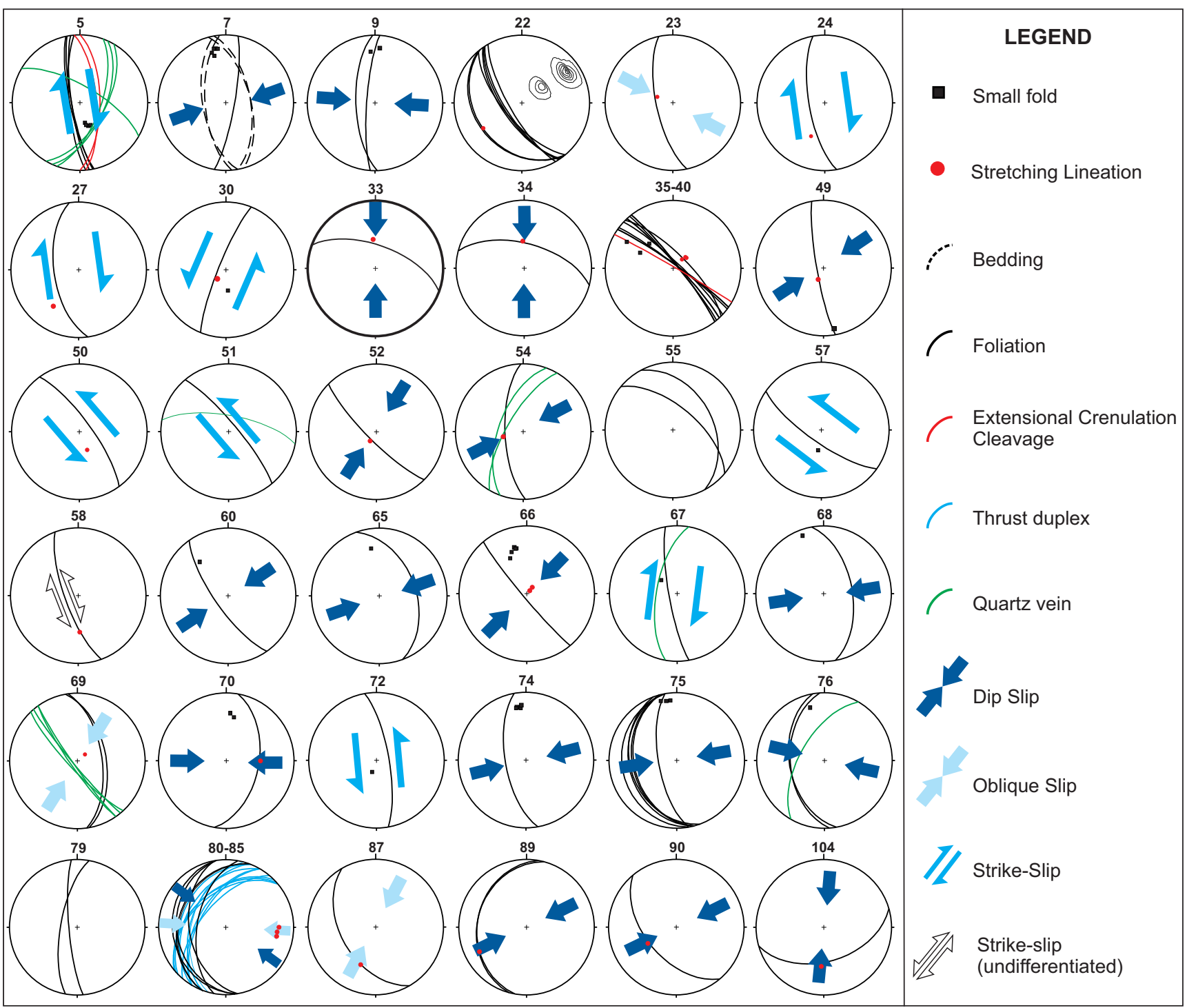

Figure 9. Lower-hemisphere Schmidt stereonet projection of structural data from the western KkGB, the eastern KKGB and parts of the Jergul Complex. 36 stereonets are presented for localities in which viable kinematic indicators were observed from a total of 109 visited localities. Fig. 10 shows the location of each stereonet/locality. The structural data shows that, despite the fact that the large-scale regional geophysical picture shows on map view only a component of predominant sinistral shearing, the kinematics at the outcrop can be far more complicated. Both dipslip, oblique slip and pure strike-slip kinematics are seen within the shear-zone array, suggesting a complex strain partitioning, assuming that the structures formed at the same time.

amphibolite facies metamorphic conditions, shearing continued undoubtedly down to the greenschist facies (Fig. 8H), unlike the higher-grade dip-slip thrust structures documented above.

\section{Comparison between geophysical anomaly trends and field structural data}

As documented above, there exists a geometric correspondence between the magnetic anomalies of the new survey and foliation traces or high-strain ductile shear zones. In addition, although outcrop is sparse and the field data collected are generally limited, there is also a first-order correlation between the kinematics interpreted from the aeromagnetic data (Fig. 5) and the sense of shear observed in the field (Figs. 6-8). The NE-SW-striking structures in the Jergul Complex and the NE-SW-trending KkGB correspond in the field exclusively to dip-slip thrust structures. Thrusts in the KkGB likely formed during the Svecofennian orogeny, whereas the similarly oriented structures in the Jergul Complex could be of the same age or alternatively older, e.g., Archaean and/or Palaeoproterozoic. The thrusts are found only in a few isolated, yet critical, outcrops. Fig. 7A-C show the best examples of flat-lying NESW-trending ductile shear zones, where both top-tothe-west and top-to-the-east shear senses are observed. 


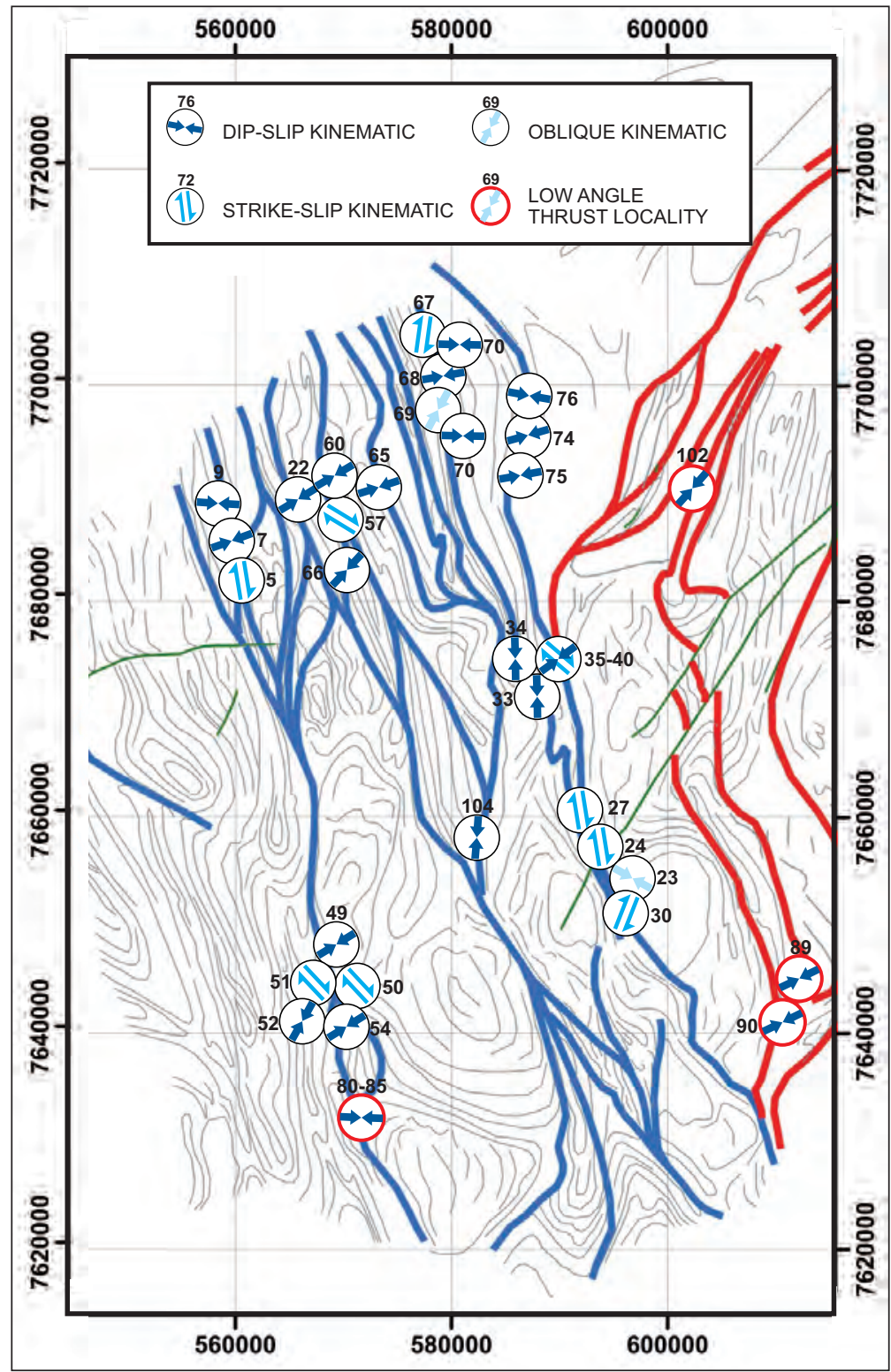

Figure 10. Map showing kinematic analysis of NNW-SSE-trending ductile shear zones in the NNW-SSE-trending part of the KkGB, constructed from the stereonets in Fig. 9. Each circular figure summarises the kinematics from an individual locality. From inside the NNWSSE part of the KKGB a complex pattern of kinematics emerges, with both mostly sinistral (but also some dextral) strike-slip and predominantly dip-slip shear zones (black circles). Note that flat-lying shear zones in the NE-SW-trending part of the KkGB, but also in isolated outcrops directly to the west of the NNW-SSE-striking western KkGB, show only dip-slip thrust kinematics (red circles).

East-verging, asymmetric, open to close folds indirectly suggest top-to-the-east thrusting (Fig. 7D). Stretching lineation data from these localities (see Locality $80-85$ in Figs. 9 \& 10) constrain a dip-slip component. At the microscale, shear-sense indicators from mylonitic rocks are generally rare. When observed, however, extensional crenulation cleavages constrain an unequivocal top-tothe-west thrust movement along gently dipping foliation planes preserved along the western margin of the NNWSSE part of the KkGB (Fig. 8E). Similarly, asymmetric feldspar porphyroclasts reflect top-to-the-east thrust movement in the NE-SW-trending part of the KkGB (Fig. 7F).
Based on geometric relationships, these thrust-related structural trends formed before the development of the cross-cutting and truncating, steeper NNW-SSE structures of the western KkGB. The NNW-SSE part of the KkGB is generally characterised by higher ductile strain, more upright steep structures and the presence of numerous shear zones and isoclinal folds visible even on the aeromagnetic data (Figs. 3, 4). Their magnetic anomaly trends reflect overall sinistral shearing, but in outcrop shear-zone kinematics can be much more complex. Fig. 9 shows a compilation of orientation data from all of the outcrops studied within the NNW-SSE part of the KkGB. For each locality where shear-sense indicators were observed (such as those shown in Fig. 8; symmetric 
porphyroclasts, asymmetric porphyroclasts, small folds, extensional crenulation cleavage), a stereonet plotting the observed stretching lineation and the derived asymmetry is used to describe the shear-zone kinematics (coloured arrows). An obvious pattern emerges from the data when considered at the regional scale. In fact, the sinistral movement observed on the regional scale geophysical dataset only reflects the map-view component of highly oblique-slip, dip-slip (Fig. 7B, F) or predominantly sinistral strike-slip movement (Fig. 7A, D) as observed at the outcrop. Both sinistral and dextral kinematics (e.g., Fig. 7C) can at times be observed in the same outcrops related to a steeply plunging stretching lineation. Specific kinematics are not diagnostic of particular spatial domains of the NNW-SSE western KkGB (Figs. 9, 10; localities 35-40). This may suggest a locally high degree of flattening across this part of the KkGB, possibly related to oblique transpression.

In summary, combining geophysical and structural data allows us to define four structural domains in the study area, which are, from east to west: 1) the Jergul Complex, 2) the NE-SW-trending eastern KkGB, 3) the NNW-SSE-trending western KkGB and 4) the Ráiseatnu Complex (Figs. 1,2).

\section{Gold mineralisation}

Studies relating mineral deposits to the structural and tectonic framework in Fennoscandia are still relatively rare, despite some important exceptions (e.g., Airo \& Kurimo, 1999; Henderson \& Kendrick, 2003; Eilu et al., 2007; Patison, 2007; Saalmann et al., 2009; Saalmann \& Niiranen, 2010).

In the Bidjovagge gold deposit in the northern part of the sinistral shear array within the western KkGB (Fig. 2), Hollander (1979) and Nilsen \& Bjørlykke (1991) observed that gold mineralisation was apparently associated with regional-scale, upright, $\mathrm{N}-\mathrm{S}$-trending folds
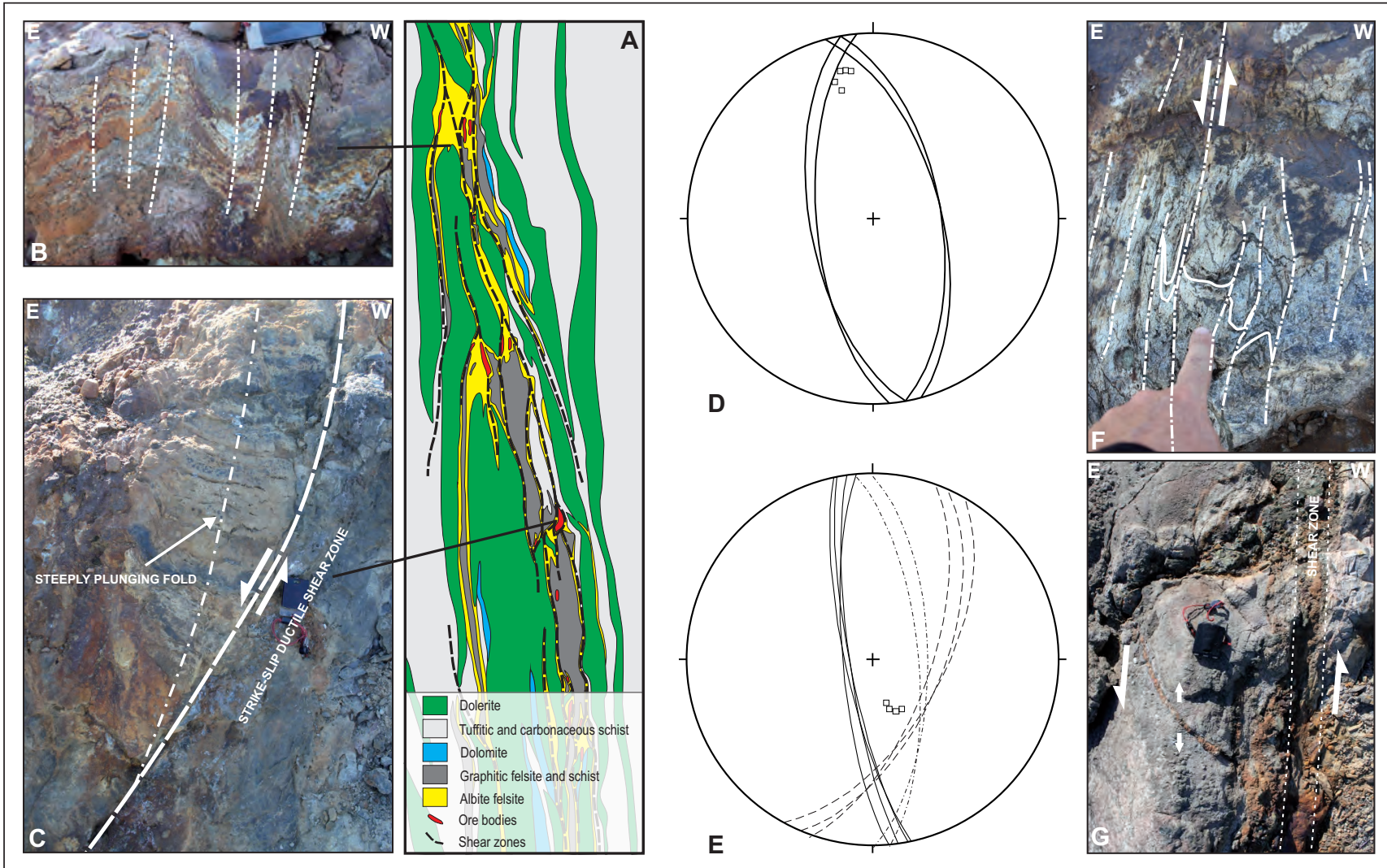

Figure 11. Field relationship between KkGB structures and gold mineralisation. (A) Detailed geological and structural map of the Bidjovagge gold deposit (after Nilsen \& Bjørlykke, 1991). Early, N-S-trending, thrust-related isoclinal anticline cut by later NNW-SSE-striking, axial planar. Strike-slip shear zones. Mineralisation is almost exclusively related to the intersection of lithological boundaries with the strike-slip shear zones. (B) Flat-lying fold hinges in open, $N$-S-striking folds just outside the mineralised zone at the Bidjovagge gold deposit. (C) A steeply plunging fold limb (dot-dashed line) is truncated and deflected by a steep, sinistral, strike-slip shear zone in the mineralised zone at the Bidjovagge gold deposit. (D) Lower hemisphere Schmidt projection of fold orientation data from the locality shown in B. Great circles: fold limbs; Squares: fold axes. (E) Lower-hemisphere Schmidt projection of structural data from the locality shown in C. Solid great circles: foliation; Dashed great circles: en échelon quartz veins. Dot-dashed great circles: extensional crenulation cleavage planes; Squares: fold axes. (F) Steeply plunging, N-Strending microfolds with axial planar, N-S-trending, micro-shear zones displacing and segmenting the folds. (G) Sinistral en échelon quartz veins associated with a steep, $N-S$, sinistral shear zone. 
(Fig. 11A). However, they did not characterise the details of, or differentiate different fold geometries between, the mineralised domains and the immediate surroundings. In the vicinity of Bidjovagge, but outside of the mineralised zone, we observe only large-scale $\mathrm{N}$-S-striking folds with gently N-plunging fold axes (Fig. 11B, D). On the basis of their geometry and orientation, we propose that these folds belong structurally to the early dip-slip, thrust-related deformation still well preserved within the eastern NE-SW-trending KkGB. In the mineralised zone, however, we find a more complex folding style. In addition to the regional upright and shallow fold geometries typical of the non-mineralised domains (as seen in Fig. 11A), more localised (with wavelengths of only up to a few tens of centimetres), steeply plunging mesoscale folds are also documented (Fig. 11C, E). They fold an older mylonitic fabric, whose origin remains as of yet unclear, but which we prefer to interpret as being genetically connected with the NNW-SSE-striking sinistral shear zones of the western KkGB. These folds are in close spatial association with small-scale, N-S-trending, ductile shear zones parallel to the axial surfaces (black lines in Fig. 11A). Nilsen \& Bjørlykke (1991) were the first to describe these N-S-striking shear zones. Shearing caused localised fold disruption and segmentation (Fig. 11C, F). If these shear zones are co-genetic with the development of the gently plunging regional folds, they should display dip-slip kinematics. However, our observations show that their spatial relationship to the steep folds and the presence of locally preserved secondary structures such as extensional crenulation cleavage and en echelon, mineralised veins (Fig. 11G), suggest that the shear zones accommodated instead predominantly strike-slip displacement and are genetically related to the development of the steeply plunging folds. We therefore interpret the coupled shear zones and steeply plunging fold structures within the mineralised zone as broadly cogenetic and resulting from strain accommodation that cuts and thus postdates the larger-scale, regional, thrust-related folds.

Fig. 12 shows that the mineralisation at Bidjovagge can be observed in a few key structural sites within the previously discussed structural framework. Mineralisation can fill dilational sites within the strike-slip shear zones as a breccia fill (as shown in Fig. 11C). Dilation zones can occur in strike-slip shear zone related drag structures connected to parasitic fold development (map in Fig. 11A). Gold can also occur in strike-slip related tension gashes that we interpret as second-order structures to the main N-S shear zones (see Fig. 11G). Although not directly observed, it is also possible that gold occurs in dilational zones within reworked, thrust-related fold hinges. Mineralisation may also potentially occur in reworked parasitic folds on the regional-scale, shallowly plunging, upright folds.

\section{Discussion}

\section{Geometry and kinematic evolution of the KkGB}

Based on the results presented above, we believe that the two separate tectonic compartments of the KkGB, each with a specific and different geometrical signature and tectonic history, account for the arcuate shape of the KkGB (Figs. 1, 2). Fig. 13 shows our schematic model for the development of the KkGB and this tentative model will be discussed in the following.

The NE-SW-trending eastern KkGB is characterised by generally low-strained, flat-lying and heterogeneously sheared rocks that constrain an early dip-slip thrusting episode (Fig. 13A) with generally top-to-the-east (but also minor top-to-the-west) shortening in response to an approximate E-W contraction (Fig. 6B). Associated NESW-trending, upright, open and east-vergent folds are common. We believe that this sector of the belt preserves the earliest increments of the local Palaeoproterozoic tectonic history as previously described also in the KjGB (Braathen \& Davidsen, 2000) and in the West Troms Basement Complex (WTBC; Bergh et al., 2010). This phase of shortening produced a double-vergence, NNWSSE-trending fold and thrust belt, which emplaced thrust sheets of the KkGB structurally over both the Ráiseatnu Complex to the west and the Jergul Complex to the east (Figs. 1, 13A). The interpretation of gravity data in a profile across the sinistral shear zone array (Fig. 13D; Olesen \& Sandstad, 1993) shows a remarkably similar geometry to our tectonic interpretation, with a central steep zone with opposing dips cutting a more flat-lying and gently folded geometry in the east. Significant inheritance of Archaean structural elements seems highly unlikely, as discussed by Bingen et al. (this volume) and we believe that the preserved structural grain is thus Palaeoproterozoic.

The internal architecture of the NNW-SSE sector of the western KkGB indicates a very pervasive reworking of this early fold and thrust belt by a later, ductile, sinistral transpressive event (Fig. 13B). After continued transpression and overtightening of the folds associated with initial dip-slip thrusting, a network of presumably late Svecofennian ductile shear zones variably transposed the earlier thrust and fold belt foliation that now occurs only in patchily preserved asymmetric lenses within the NNW-SSE KkGB. Based on the observed kinematic complexity, we propose that this NNW-SSE, regional-scale, shear array formed in response to a high degree of obliquity accommodated during later stages of the orogeny, which led to oblique-slip deformation that partitioned into coexisting sinistral and dextral strikeslip and dip-slip shearing (Fig. 13C). Several conflicting shear senses can indeed be observed in the same outcrop. Such complex kinematics have previously been attributed to strain partitioning during oblique or inclined 


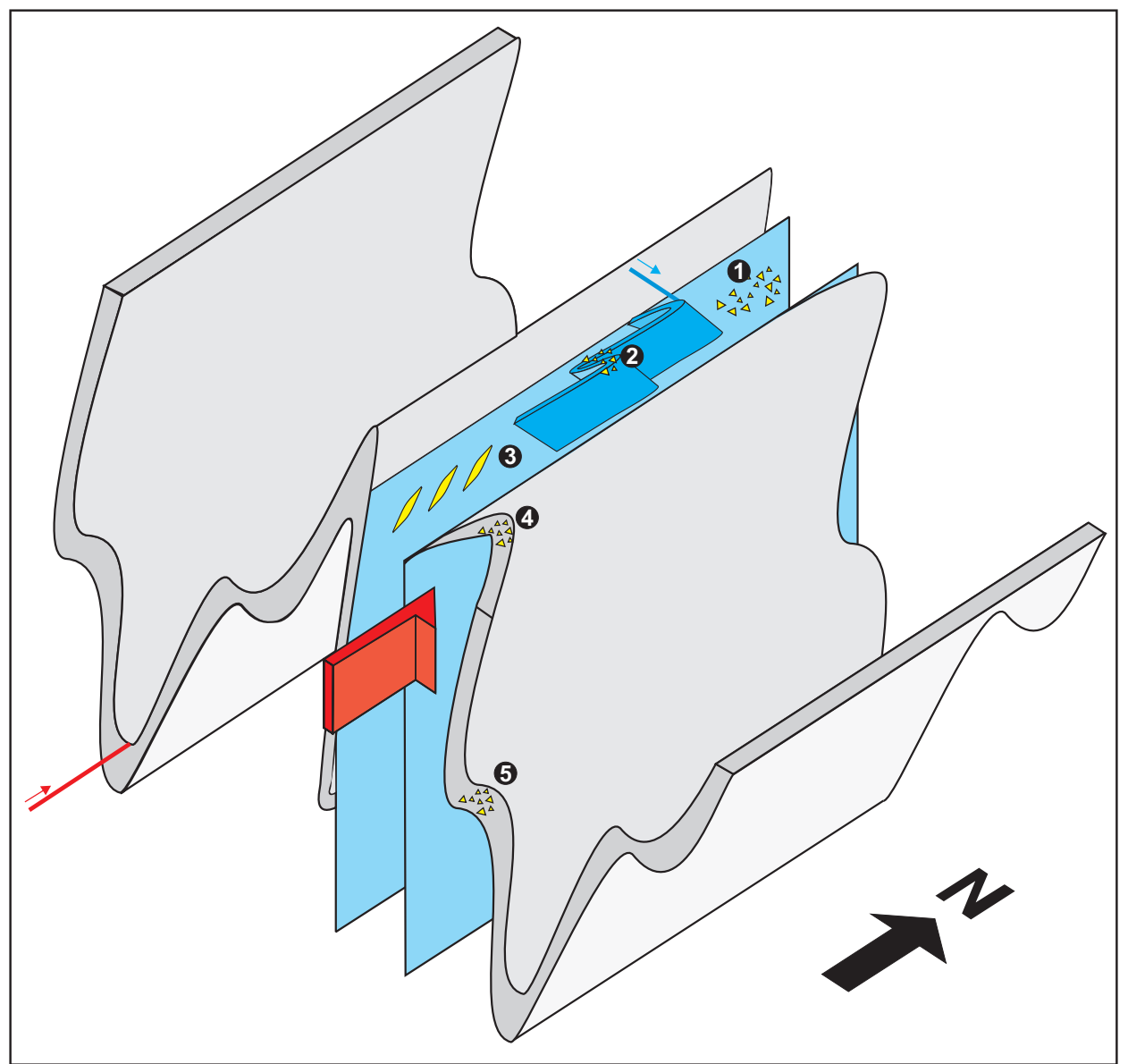

Figure 12. Schematic model for the development of gold mineralisation in the Bidjovagge gold deposit in the context of the tectonic model. The grey folds represent the regional, early, dip-slip related folds with $\mathrm{N}$-S-trending axes and shallowly plunging hinges (red arrow). The blue colour represents a later strike-slip shear zone which forms axial planar to the earlier formed folds, likely exploiting the mechanical weakness of the axial planar cleavage. These shear zones are associated with steeply plunging folds, located exclusively within or in the vicinity of the shear zone (blue arrow). Mineralisation (in yellow) can occur in several sites: 1 - As a dilation-filling mass within the shear zone as a breccia fill (as shown in Fig. 11C), 2 - Within the shear zone related fold structures, possibly in dilation zones related to parasitic fold development (this is clearly shown in the detailed map in Fig. 11A), 3 - Within tension gashes (see Fig. 11G), 4 - Mineralisation is also possible in dilational zones in reworked, thrust-related fold closures but not directly observed, 5 - Mineralisation is also possible in dilational zones in reworked parasitic folds near to the strike-slip shear zone but not directly observed.

transpression (e.g., Holdsworth et al., 2002; Jones et al., 2004; Tavarnelli et al., 2004; Bergh et al., 2010; 2015; Viola \& Henderson, 2010; Angvik, 2014). Shearing along the NNW-SSE-trending western KkGB postdates the $1865 \mathrm{Ma}$ Vuolgamašvuopmi granite (area D in Fig. 5; Bingen et al., this volume), which is truncated by the sinistral shear array of the western KkGB. Our reconstruction is corroborated by the observation that early thrust shear zones appear to have formed at amphibolite-facies metamorphic grade, while strike-slip oblique shear zones formed at amphibolite grade and extended into greenschist-facies conditions during a retrogressive evolution likely related to equilibration at lower crustal depths during progressive uplift and exhumation.

It is not possible at present to constrain the amount of displacement accommodated along the western KkGB. As discussed above, the sinistral shear zones therein define several mega-scale duplex geometries that cumulatively may have accommodated tens or even hundreds of kilometres of displacement, in agreement with the previous map-scale observations of Berthelsen \& Marker (1986), who suggested up to $120 \mathrm{~km}$ of left-lateral movement based on the displacement of the Sirkka Line farther south in Finland (Fig. 1).

Olesen \& Sandstad (1993) suggested that the structures of the Mierujàvri-Sværholt Fault Zone (eastern KkGB in this study) are continuous with the Karesuando-Arjeplog Shear Zone (KASZ) and Kiruna-Naimakka Shear Zone (KNSZ) in northern Sweden (Fig. 1). However, south of the KkGB we observe a regional-scale sinistral deflection of the KASZ and the KNSZ, thus suggesting considerable displacement on the KkGB sinistral-shear array (see Fig. 1) consistent with the observations of Berthelsen \& Marker (1986).

When comparing the gneissic sequences of the Jergul 


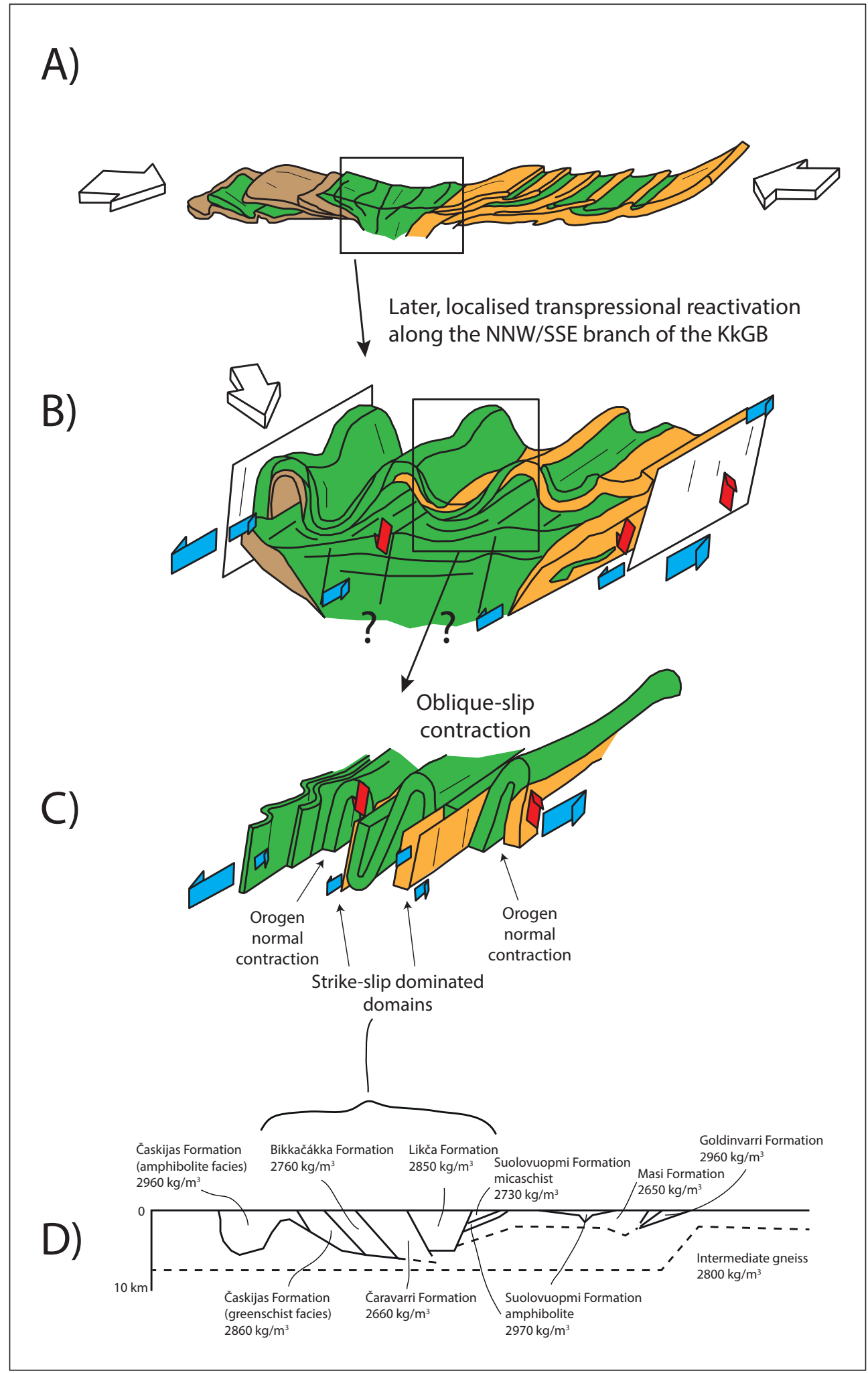

Figure 13. Schematic tectonic model for the Svecofennian development of the KkGB. View from the southeast. Model adapted from Bergh et al. (2010) and inspired by the similarities in structural history with their model for the evolution of the WTBC (West Troms Basement Complex). (A) After rifting and formation of the KkGB volcano-sedimentary successions, early Svecofennian crustal shortening produced a low-angle, double-vergent, thin-skinned fold and thrust belt juxtaposing the tectonised KkGB metasupracrustals and metavolcanics over the Ráiseatnu Complex gneisses in the west and the Jergul Complex gneisses in the east with an approximate E-W or NW-SE shortening trend. (B) Mid-late Svecofennian, oblique, WNW-ESE crustal shortening steepened and tightened the early thrust structures and new NNW-SSE-striking shear zones developed. These have complex kinematics with significant oblique-slip accommodation resulting in strain partitioning and triclinic strain. (C) Further oblique transpression resulted in the compartmentalisation of the orogen and enhanced strain partitioning into zones of strike-slip and dip-slip deformation. (D) Interpreted gravity profile (from Olesen \& Sandstad, 1993) from the northern part of the KkGB (for location see Fig. 3A) intersecting both the steeply dipping. NNW-SSE, sinistral shear-zone array and the more 'thrust-only' phase of the flatlying eastern KkGB. The first-order geometry of this model fits nicely the proposed schematic Svecofennian tectonic model. 
and Ráiseatnu complexes, which are juxtaposed against the KkGB, we have concluded that the aeromagnetic signatures for these two domains are different and none of the interpreted dextral structures of the eastern KkGB are present in the Ráiseatnu Complex. This may suggest that the Jergul and Ráiseatnu are terranes juxtaposed along the sinistral shear-zone array of the western KkGB with large lateral displacements.

The large geochronological break documented on opposing sides of the sinistral shear zone array in the NNWSSE-trending part of the KkGB by Bingen et al. (this volume) is also strong and independent evidence of the fact that the KkGB indeed represents a major tectonic displacement zone.

\section{Comparison with other Archaean- Palaeoproterozoic domains in northern Norway}

Fig. 1 shows the geographical relationship among the disparate Archaean-Palaeoproterozoic basement domains in northern Norway with the goal to place our KkGB work within a regional context. A direct comparison of the different Archaean-Palaeoproterozoic basement areas is difficult due to the extensive Caledonian cover and general poor outcrop levels, particularly in the KkGB and $\mathrm{KjGB}$, and the commonly isolated nature of individual tectonic windows. Comparison of the complex structural evolution of the Palaeoproterozoic greenstone belts in Norway with similar belts in northern Fennoscandia and even farther afield (Griffin et al., 1978; Friend \& Kinny, 2001; Park et al., 2001; Park, 2005; Daly et al., 2006; Bergh et al., 2012) is thus inherently problematic. However, these difficulties notwithstanding, we discuss below some striking tectonic similarities of these areas, along with key dissimilarities to the KkGB.

Bergh et al. (2010) carried out the most comprehensive structural study of Palaeoproterozoic shearzone architecture in Fennoscandia to the present day, by undertaking a detailed structural analysis of the West Troms Basement Complex (WTBC) to the west of the Caledonian thrust sheets (Fig. 1). The WTBC (Zwaan, 1995) consists of numerous tectonic blocks of Neoarchaean gneisses separated by steep WNW-ESEtrending ductile shear zones of presumed Svecofennian age (Corfu et al., 2003) and NW-SE-trending, thin, greenstone belts (Bergh et al., 2010). The foliation in the Neoarchaean gneisses (Myhre et al., 2013) trends generally $\mathrm{N}-\mathrm{S}$ and is deflected and displaced into the Svecofennian shear zones. The foliation is folded into regional-scale, N-S-striking, tight to open folds with shallowly-plunging fold hinges. The shear zones contain dip-slip stretching lineations and indications of top-to-the-northeast displacement. The Svecofennian shear zones accommodated an initial dip-slip phase of NE-directed thrusting. Bergh et al. (2010) describe four discrete deformation phases, whereas our observations account for only two phases. However, the overall tectonic picture with early orthogonal displacement being overprinted by strike-slip deformation is similar. We see a NE-SW fabric in the Jergul Complex which, although in a different orientation, may be equivalent to the Svecofennian-reworked, Neoarchaean fabric observed between the shear zones within the WTBC, similar to that described here from the NE-SW-trending part of the KkGB. In the WTBC, thrusting deformation is overprinted by NW-SE-trending, steeply dipping, strikeslip shear zones with presumably large but ultimately unknown displacements.

The Rombak Tectonic Window (Fig. 1) is a Palaeoproterozoic inlier consisting predominantly of tonalitic and granitic rocks situated below the Palaeozoic Caledonian thrust nappes. N-S-trending, steeply dipping, linear, Palaeoproterozoic metasedimentary belts are contained within the igneous rocks and are partially intruded by them. Ductile shear zones are localised along the sedimentary-igneous contacts. Angvik (2014) described one of these crustal-scale shear zones, the Rombak-Skjomen Shear Zone (RSSZ), consisting of four episodes of ductile deformation, wherein the earliest formed a fold and thrust belt in response to overall NE-SW shortening, which was subsequently segmented and attenuated by two separate phases of steep, ductile, strike-slip shearing. In addition, Angvik (2014) documented syn-tectonic, Svecofennian-aged granites (1790 $\mathrm{Ma}$ ), which straddle the spectrum of ductile deformation, confirming that these three phases of deformation are indeed all of Svecofennian age. Similarly, the crustal-scale shear zones in the Rombak Tectonic Window display a pattern from early orthogonal top-to-the-east thrusting followed by later strike-slip deformation, the orientation of both sets of structures being broadly alike. Moreover, Angvik (op.cit.) provides the best, integrated, geochronological-structural evidence for Svecofennian deformation in Norway. However, Angvik (op.cit.) identifies four discrete deformation phases (namely two initial thrust phases) not observed in the KkGB. In addition, a final Svecofennian episode of dextral shearing described from the Rombak Window is not observed in the KkGB.

Kjøll et al. (2015) and Torgersen et al. (2015a, b) described NE-SW-trending, tight to isoclinal folds in Palaeoproterozoic metasedimentary successions of the Repparfjord Tectonic Window, and associated them with Svecofennian deformation (Fig. 1). These folds appear to be similar to the early, orthogonal, thrustrelated folds we observed in the KkGB, and likely represent the earliest orthogonal contractional phase of the Svecofennian orogeny. However, no thrust discontinuities of Svecofennian age are observed within the Repparfjord Window. Torgersen et al. (op.cit.) report that these folds are transposed by dextral shearing sub-parallel to the fold axes. Unlike in the KkGB, no sinistral structures were observed. If the regional-scale folds represent orthogonal contraction, it would appear that the major 
strike-slip phase of deformation observed in the other Palaeoproterozoic Windows is absent in the Repparfjord Window.

Braathen \& Davidsen (2000) demonstrated from the KjGB that an initial phase of west-directed thrusting, constrained to the Palaeoproterozoic by Krill (1985), was subsequently transposed into NNW-SSE-trending, strike-slip shear zones parallel to the NNE-SSW KjGB thrust front (I in Fig. 5). This is somewhat similar to the ductile history observed in the KkGB, with the difference that the orthogonal thrusting phase is only west directed. No east-directed thrusting is documented from the KjGB. In addition, the strike-slip phase appears to have segmented the thrust geometries in a much more limited manner.

In summary, the structural histories of shear zones in other Neoarchaean-Palaeoproterozoic areas in northern Norway resembles those we have observed in the Jergul Complex and the two differently oriented domains in the KkGB. The two-fold division of deformation, despite regional differences in orientation, with initial orthogonal thrusting followed by a segmentation and attenuation of the thrusting-related fabrics by strike-slip ductile shear zones, appears to be ubiquitous. However, some major dissimilarities still need to be accounted for. The Repparfjord Window appears to record only the earliest deformation phase. It is not clear if the NE-SW-trending foliation and cross-cutting discrete shear zones in the Jergul and the N-S-trending foliation in the WTBC are solely Neoarchaean or have a discrete Svecofennian overprint. Also, four phases of deformation in the WTBC and the Rombak Window may indeed be fundamentally different from the two-fold deformation observed elsewhere and, finally, the extensive dextral late shearing in the Rombak Window is not found anywhere else in northern Fennoscandia.

Further regional and detailed kinematic studies should focus on trying to reconcile these differences, integrated, when possible, with geochronological constraints. Interestingly, a recent orogenic model for Fennoscandia (Lahtinen et al., 2014) invoking orocline formation in the Svecofennian Orogeny may provide an essential key to understanding the complex tectonics.

\section{Implications for gold mineralisation and exploration strategies}

Gold is an important mineral resource in northern Fennoscandia. Its occurrence is commonly of orogenic origin (e.g., Eilu et al., 2007; Ojala, 2007; Patison, 2007) and has been documented from a number of geologi$\mathrm{cal}$ and structural settings, although its structurally-controlled endowment and the tectonic processes steering its deposition remain relatively poorly explored. Ihlen \& Furuhaug (2000), for example, suggested that although extensive gold anomalies occur in a Neoarchaean greenstone belt (Motuza et al., 2001) on the island of Ringvassøy (which is part of the WTBC), they are structurally controlled by Palaeoproterozoic deformation. Saalmann et al. (2009) constrained gold mineralisation in southern Finland to a late Palaeoproterozoic, dextraloblique transpression. Similarly, Angvik (2014) demonstrated that gold in the Rombak Window is most likely related to the latest phase of ductile dextral transpression during polyphase Palaeoproterozoic deformation. Saalmann \& Niiranen (2010) documented in detail the relationship between structures, hydrothermal alteration and gold mineralisation in the Hanhimaa Shear Zone in northern Finland.

In the Bidjovagge gold mine, the legacy of two different deformation episodes is present (Fig. 12). Unmineralised, meso-scale, N-S-trending, tight to isoclinal folds have shallowly north-plunging axes. These fold geometries are most readily attributed to the relatively early thrusting phase of Svecofennian deformation. Although we observe no direct link between the observed thrusts and the regional-scale folds in the mine, small-scale folds are observed with the same geometry. These early folds are segmented by steeply dipping, N-S-striking shear zones which have a predominantly sinistral strike-slip shear sense and correlate with the NNW-SSE, sinistral shearzone array interpreted from the geophysical data (Fig. 3). It is these shear zones that are mineralised. Axial surfaces of steeply plunging folds that are associated with the strike-slip shear zones plunge steeply to the north. They are commonly asymmetric and display drag structures against the sinistral shear zones and are truncated against the shear zones.

In the Rombak Tectonic Window, Angvik (2014) demonstrated four different phases of mineralisation with complex remobilisation and deformation, that are spatially and temporally linked to the development of the RSSZ. Primary, syn-genetic, SEDEX mineralisation was documented parallel to the bedding in the metasediments. However, most gold mineralisation is attributed to the late Svecofennian sinistral and dextral shear zones. $\mathrm{U}-\mathrm{Pb}$ dating of well-constrained syn-tectonic granites in the RTW, and therefore the age of gold mineralisation, is well constrained to $1790 \mathrm{Ma}$ (Angvik, 2014). In the Repparfjord Tectonic Window, Torgersen et al. (2015a) documented $\mathrm{Cu}$ mineralisation formed in a dextral transpressive regime and interpreted that to also represent the initiation of folding, constraining the age of mineralisation to $2069 \pm 14 \mathrm{Ma}$ (Torgersen et al., 2015a), that is, much earlier than the interpreted $1880 \mathrm{Ma}$ age of mineralisation in the KkGB (Bjørlykke et al., 1990). Moreover, the age of mineralisation in the KkGB is $c .100$ Ma older than that in the RTW, even though the same structural geometries are mineralised. Gold mineralisation is present in the Karasjok Greenstone Belt but is not particularly well constrained, structurally or otherwise. It is therefore clear that different tectonic histories are 
present in different parts of the Svecofennian orogen and that mineralisations are attributable to different tectonic events occurring at different times.

In terms of implications for future exploration, the above observations and inferences demonstrate that gold mineralisation is intimately associated with the Svecofennian orogen. However, comparison of the structural, kinematic and tectonic evolution of the different areas reveals a complex picture. Evidence shows that the Svecofennian orogen resulted from several different deformation phases and that not all of them are detectable throughout the belt. Fragmentary but tantalising evidence shows that mineralisation is not necessarily related to one phase of deformation or to one temporal event. Therefore, in order to create a predictive mineralisation model in a particular area, the kinematic and structural evolution needs to be documented in detail first and the relationship of the mineralisation to this model must be unravelled. This has already been done in detail in several areas in Norway (e.g., Angvik, 2014; Torgersen et al., 2015a) but much work remains to be done. The fragmentary evidence presented here for gold mineralisation for the KkGB highlights the need for such a systematic approach.

\section{Implications for Palaeoproterozoic tectonics}

The nature and evolution of continent building processes during the Palaeoproterozoic, and the tectonic processes that facilitated them, are still contentious. In particular, many believe that the tectonic processes occurring within the Earth's crust during the Palaeoproterozoic were identical to those we observe today. At the other end of the spectrum, many propose instead dome-and-basin type structures for the early Earth, where the development of diapir-type features associated with buoyant gneissic domes led to gravitational instability and what is often called 'sagduction' of the intervening sediment basins (Chardon et al., 1996, 1998). This peculiar type of 'tectonics' was more prevalent in the Archaean (e.g., Bouhallier et al., 1995; Chardon et al., 1996; Chadwick et al., 2000; Thébauda \& Reyb, 2013; Van Kranendonk et al., 2004) but some examples exist from the Palaeoproterozoic (Vidal et al., 2009) and also parts of the 'hotter' and 'weaker' Palaeoproterozoic and Mesoproterozoic crust in Fennoscandia (Cagnard et al., 2007; Bingen \& Viola, 2015). Some believe that 'modern' subduction tectonics, and therefore, modern fold and thrust belts, did not appear until the Neoproterozoic (Stern, 2005; Vidal et al., 2009). Moreover, Chardon et al. (2009) suggested that the presence of dome-and-basin type structures and sagduction may not be just restricted to the Precambrian but occurred also at other times in Ultra Hot Orogens. However, the presence of this type of subsidence tectonics is eminently possible to test, as opposing senses of more or less dip-slip extensional shear should be present on either side of the 'sagducted' sedimentary sequence, provided these are not overprinted by later ductile reactivation. Our results from the KkGB clearly demonstrate that there is at least no preserved evidence for a sagduction-type orogen for the sedimentary basin that is now the KkGB. In such a case, opposing senses of extensional shear would have been observed on the basin margins, both top-down towards the basin centre. That this is not the case is testament to the high degree of postsedimentary deformation and extreme lateral translation of at least the NNW-SSE part of the basin that today is observed as a major crustal-scale sinistral shear-zone array.

\section{Conclusions}

- A newly acquired and compiled high-resolution aeromagnetic survey over the Kautokeino Greenstone Belt (KkGB) and the neighbouring Ráiseatnu and Jergul granitic complexes reveals the presence of four distinct domains with different geophysical signatures and structural grains. The interpretation of this geophysical data lays the foundation for our field structural analysis.

- The KkGB is made up of two differently oriented parts with different structural styles and magnetic signatures. The eastern KkGB is NE-SW trending and has weak anomalies with a rather homogeneous geophysical signature. The western KKGB is NNW-SSE trending with sharp, short-wavelength anomalies. The anomalies in the eastern $\mathrm{KkGB}$ are deflected into the western KKGB.

- Structural field analysis demonstrates that most of the discontinuities in the geophysical anomalies correspond to mylonitic shear zones. Kinematic analysis reveals that the NE-SW-oriented structures found mostly in the Jergul Complex and the eastern KkGB are flat-lying, dip-slip to oblique thrust structures that are either west or east vergent. The NNW-SSE anomalies in the western KKGB are instead generally steeply dipping, mylonitic shear zones with both dip-slip and strike-slip kinematics. We interpret these as truncating the dip-slip thrust structures that mostly occur in an NE-SW trend.

- Our integrated data suggest an early NE-SW-directed compressional phase that generated a double-vergent, fold and thrust belt. This phase of deformation is preserved in the most northerly, least tectonised, NE-SW-trending part of the KkGB. Subsequently, a cross-cutting NNW-SSE-trending, $40 \mathrm{~km}$-wide, high-strain, sinistral shear-zone duplex array formed in the western KkGB. This produced a NNW-SSEtrending 'flower structure,', which emplaced the Kautokeino Greenstone Belt rocks structurally over both the Ráiseatnu Complex to the west and the Jergul Complex to the east. The KkGB is therefore tectonically compartmentalised into two domains; (1) a NE-SW trending, dip-slip thrust only part and (2) 
a western high-strain, NNW-SSE-striking sinistral shear-zone array.

- Comparison of this model with other ArchaeanPalaeoproterozoic areas in Norway shows a large degree of similarity, with flat-lying, dip-slip thrust structures formed first and subsequently reworked by strike-slip dominated transpression, namely in the Karasjok Greenstone Belt, the Ringvassøy Greenstone Belt, the West Troms Basement Complex and the Rombak Tectonic Window, suggesting a similar tectonic evolution.

- Gold mineralisation at the Bidjovagge mine is structurally controlled and appears to be spatially and temporally related to strain accommodation associated with the NNW-SSE-trending ductile shear zone of the western $\mathrm{KkGB}$.

Acknowledgements. This study was funded by the Mineral Resources in North Norway (MINN) program initiated by the Norwegian government to further develop the mineral industry in Norway. We are grateful to Jan Sverre Sandstad, the coordinator of the MINN program and the project leader of the West Finnmark Project, for introducing us to the wonders of Finnmark. We would like to thank Odleiv Olesen for leading the MINN fixed-wing magnetic surveys at NGU and MarieAndrée Dumais for the implemented quality-control procedures. We also thank Novatem Airborne geophysics and EON Geosciences Inc. for the data acquisition. The Geological Survey of Finland (GTK) is thanked for providing the aeromagnetic data in the Karasjok area. We are grateful to Steffen G. Bergh and Enrico Tavarnelli for constructive reviews that have greatly improved the manuscript, and to Trond Slagstad and David Roberts for their help with the editorial work.

\section{References}

Airo, M.L. \& Kurimo, M. 1999: Palaeoproterozoic Suukisjoki maficultramafic intrusion in northern Finland: combined aerogeophysical, geological and tectonic studies. Geological Survey of Finland Special Paper 27, 143-151.

Angvik, T.L. 2014: Structural development and metallogenesis of Paleoproterozoic volcano-sedimentary rocks of the Rombak Tectonic Window. $\mathrm{PhD}$ thesis, University of Tromsø, The Arctic University of Norway, 248 pp.

Armitage, P.E.B. \& Bergh, S.G. 2005: Structural development of the Mjelde-Skorelvvatn Zone on Kvaløya, Troms: a metasupracrustal shear belt in the Precambrian West Troms Basement Complex, North Norway. Norwegian Journal of Geology 85, 117-132.

Bark, G. \& Weihed, P. 2007: Orogenic gold in the Lycksele- Storuman ore province, northern Sweden; the Palaeoproterozoic Faboliden deposit. Ore Geology Reviews 32, 431-451.

Bergh, S.G., Kullerud, K., Armitage, P.E.B., Zwaan, K.B., Corfu, F., Ravna, E.J.K. \& Myhre, P.I. 2010: Neoarchaean to Svecofennian tectono-magmatic evolution of the West Troms Basement Complex, North Norway. Norwegian Journal of Geology 90, 21-48.

Bergh, S.G., Corfu, F., Myhre, P.I., Kullerud, K., Armitage, P.E.B., Zwaan, K.B., Ravna, E.K., Holdsworth, R.E. \& Chattopadhya, A. 2012: Was the Precambrian Basement of Western Troms and Lofoten-Vesterålen in Northern Norway Linked to the Lewisian of Scotland? A Comparison of Crustal Components, Tectonic Evolution and Amalgamation History. Tectonics; Recent Advances Chapter 11, 283-330.

Bergh, S.G., Corfu, F., Priyatkina, N., Kullerud, K. \& Myhre, P.I. 2015
Multiple post-Svecofennian 1750-1560 Ma pegmatite dykes in Archaean-Palaeoproterozoic rocks of the West Troms Basement Complex, North Norway: Geological significance and regional implications. Precambrian Research 266, 425-439.

Bergman, S., Billström, K., Persson, P.O., Skiöld, T. \& Evins, P. 2006: $\mathrm{U}-\mathrm{Pb}$ age evidence for repeated Palaeoproterozoic metamorphism and deformation near the Pajala shear zone in the northern Fennoscandian shield. Geologiska Föreningen $i$ Stockholm Förhandlingar 128, 7-20.

Berthelsen, A. \& Marker, M. 1986: Tectonics of the Kola collision suture and adjacent Archaean and early Proterozoic terrains in the northeastern region of the Baltic Shield. Tectonophysics 126, 31-55.

Beunk, F.F. \& Page, L.M. 2001: Structural evolution of accretional continental margin of the Palaeoproterozoic Svecofennian orogen in southern Sweden. Tectonophysics 339, 67-92.

Bingen, B., Solli, A., Torgersen, E., Viola, G., Sandstad, J.S., Whitehouse, M.J., Ganerød, M. \& Nasuti, A. 2015: Geochronology of the Palaeoproterozoic Kautokeino Greenstone Belt, Finnmark, northern Norway: Tectonic implications in a Fennoscandia context. Norwegian Journal of Geology 95, 365-396. http://dx.doi. org/10.17850/njg95-3-09.

Bingen, B. \& Viola, G. 2015: Paired c. 1150 Ma compression-extension belts in S Norway and the geodynamics of Grenvillian orogens, $25^{\text {th }}$ Goldschmidt Conference, 16th-21st August, 2015, Prague, Czech Republic.

Bjørlykke, A., Hagen, R. \& Søderholm, K. 1987: Bidjovagge coppergold deposit in Finnmark, northern Norway. Economic Geology 82, 2059-2075.

Bjørlykke, A., Cumming, G.L. \& Krstic, D. 1990: New isotopic data from davidites and sulfides in the Bidjovagge gold-copper deposit, Finnmark, northern Norway. Mineralogy and Petrology 43, 1-12.

Bouhallier, H. Chardon, D. \& Choukroune, P. 1995: Strain patterns in Archaean dome-and-basin structures: The Dharwar craton (Karnataka, South India). Earth and Planetary Science Letters 135, 57-75.

Braathen, A. \& Davidsen, B. 2000: Structure and stratigraphy of the Palaeoproterozoic Karasjok Greenstone Belt, north Norway regional implications. Norwegian Journal of Geology 80, 33-50.

Cagnard, F., Gapais, D. \& Barbey, P. 2007: Collision tectonics involving juvenile crust: The example of the southern Finnish Svecofennides. Precambrian Research 154, 125-141.

Chadwick, B., Vasudev, V.N. \& Hegde, G.V. 2000: The Dharwar craton, southern India, interpreted as the result of Late Archaean oblique convergence. Precambrian Research 99, 91-111.

Chardon, D., Choukroune, P. \& Jayananda, M. 1996: Strain patterns, decollement and incipient sagducted greenstone terrains in the Archaean Dharwar craton (south India). Journal of Structural Geology 18, 991-1004.

Chardon, D., Choukroune, P. \& Jayananda, M. 1998: Sinking of the Dharwar Basin (South India): implications for Archaean tectonics. Precambrian Research 91, 15-39.

Chardon, D., Gapais, D. \& Cagnard, F. 2009: Flow of ultra-hot orogens: A view from the Precambrian, clues for the Phanerozoic. Tectonophysics 477, 105-118.

Corfu, F., Armitage, P.E.B., Kullerud, K. \& Bergh, S.G. 2003: Preliminary $\mathrm{U}-\mathrm{Pb}$ geochronology in the West Troms Basement Complex, North Norway: Archaean and Palaeoproterozoic events and younger overprints. Geological Survey of Norway Bulletin 441, 61-72.

Daly, J.S., Balagansky, V.V., Timmerman, M.J. \& Whitehouse, M.J. 2006: The Lapland-Kola orogen: Palaeoproterozoic collision and accretion of the northern Fennoscandian lithosphere. Geological Society London Memoirs 32, 579-598.

Eilu, P., Sorjonen-Ward, P., Nurmi, P. \& Niiranen, T. 2003: A Review of Gold Mineralization Styles in Finland. Economic Geology 98, 13291353.

Eilu, P., Pankka, H., Keinänen, V., Kortelainen, V., Niiranen, T. \& Pulkkinen, E. 2007: Characteristics of gold mineralisation in the 
greenstone belts of northern Finland. Geological Survey of Finland Special Paper 44, 57-106.

Eisenlohr, B.N., Groves, D. \& Partington, G.A. 1989: Crustal-scale shear zones and their significance to Archaean gold mineralization in Western Australia. Mineralium Deposita 24, 1-8.

EON Geosciences Inc. 2015: Troms-Finnmark fixed wing aeromagnetic survey 2014 (TROFI-14). EON Geosciences Inc. Report, Montréal, Quebec, Canada, 34 pp.

Ettner, D.C., Bjørlykke, A. \& Andersen, T. 1993: Fluid evolution and $\mathrm{Au}-\mathrm{Cu}$ genesis along a shear zone: a regional fluid inclusion study of shear zone-hosted alteration and gold and copper mineralization in the Kautokeino greenstone Belt, Finnmark, Norway. Journal of Geochemical Exploration 3, 233-267.

Ettner, D.C., Bjørlykke, A. \& Andersen, T. 1994: Fluid evolution and $\mathrm{Au}-\mathrm{Cu}$ genesis along a shear zone: a regional fluid inclusion study of shear zone-hosted alteration and gold and copper mineralization in the Kautokeino greenstone belt, Finnmark, Norway. Mineralium Deposita 29, 16-29.

Fareth, E. 1979: Geology of the Altenes area, Alta-Kvænangen window, North Norway. Geological Survey of Norway Bulletin 351, 13-29.

Friend, P.D. \& Kinny, P.D. 2001: A reappraisal of the Lewisian Gneiss Complex: geochronological evidence for its tectonic assembly from disparate terranes in the Proterozoic. Contributions to Mineral and Petrology 42, 198-218.

Gaál, G. 1990: Tectonic styles of early Proterozoic ore deposition in the Fennoscandian Shield. Precambrian Research 46, 83-114.

Gaál, G. \& Gorbatchev, R. 1987: An outline of the Precambrian evolution of the Baltic Shield. Precambrian Research 35, 15-52.

Gaál, G. \& Groves, D.I. 1990: Preface to the special issue on "Precambrian Ore Deposits related to Tectonics". Precambrian Research 46, 1-2.

Gautier, A.M., Gulacar, F. \& Delaloye, M. 1979: K-Ar age determinations of the Alta-Kvænangen window rocks, northern Norway. Norwegian Journal of Geology 2, 155-159.

Geological Survey of Finland (GTK) Internal Technical Report 2007: Airborne Geophysical Survey Finnmark, Norway. 50pp.

Geological Survey of Finland (GTK) Internal Technical Report 2008: Airborne Geophysical Survey Skuvvanvarri Finnmark, Norway. $41 \mathrm{pp}$.

Geological Survey of Finland (GTK) Internal Technical Report 2009: Airborne Geophysical Survey Russevatna and Gosjohka Finnmark, Norway. 55pp.

Gerya, T. 2014: Precambrian geodynamics: Concepts and models. Gondwana Research 25, 442-463.

Goldfarb, R.J., Groves, D.I. \& Gardoll, S. 2001: Orogenic gold and geologic time: a global synthesis. Ore Geology Reviews 18, 1-75.

Goodenough, K.M., Crowley, G.C., Krabbendam, M. \& Parry, S.F. 2013: New U-Pb age constraints for the Laxford Shear Zone, NW Scotland: Evidence for tectono-magmatic processes associated with the formation of a Paleoproterozoic supercontinent. Precambrian Research 233, 1-19.

Gorbatchev, R. \& Bogdanova, S. 1993: Frontiers in the Baltic Shield. Precambrian Research 64, 3-21.

Griffin, W.L., Taylor, P.N., Hakkinen, J.W., Heier, K.S., Iden, I.K., Krogh, E.J., Malm, O., Olsen, K.I., Ormaasen, D.E. \& Tveten, E. 1978: Archaean and Proterozoic crustal evolution in Lofoten-Vesterålen, N. Norway. Journal of the Geological Society of London 135, 629647.

Groves, D.I. \& Bennett, J.M. 1993: Special issue - structural setting and controls on mineral-deposits - extracts from the Kalgoorlie 91 conference on structural geology in mining and exploration Introduction. Ore Geology Reviews 8, 1-1.

Groves, D.I., Goldfarb, R.J., Gebre-Mariam, M., Hagemann, S.G. \& Robert, F. 1998: Orogenic gold deposits: A proposed classification in the context of their crustal distribution and relationship to other gold deposit types. Ore Geology Reviews 13, 7-27.

Hamilton, W.B. 2011: Plate tectonics began in Neoproterozoic time, and plumes from deep mantle have never operated. Lithos 123 , $1-20$.

Hanmer, S. 1986: Asymmetrical pull-aparts and foliation fish as kinematic indicators. Journal of Structural Geology 8, 111-115.

Henderson, I.H.C. \& Kendrick, M. 2003: Structural controls on graphite mineralisation, Senja, Troms. Geological Survey of Norway Report 2003.011, 110 pp.

Henderson, I.H.C., Niiranen, T., Bergman, S., Krasotkin, S., Gonzalez, J. \& Saalman, K.: Structural controls on gold mineralisation in the Fennoscandian Gold Transect. Geological Survey of Finland Special Paper (in prep.).

Henkel, H. 1991: Magnetic crustal structures in Northern Fennoscandia. Tectonophysics 192, 69-79.

Hinze, W.J., Von Frese, R.B. \& Saad, A.H. 2013: Gravity and Magnetic Exploration: Principles, Practices and Applications. Cambridge University Press, New York, 512 pp.

Holdsworth, R.E., Tavarnelli, E., Clegg, P., Pinheiro, R.V.L., Jones, R.R. \& McCaffrey, K.J.W. 2002: Domainal deformation patterns and strain partitioning during transpression: an example from the Southern Uplands terrane. Scotland Journal of the Geological Society 159, 401-415.

Hollander, N.B. 1979: The geology of the Bidjovagge Mining Field, western Finnmark, Norway. Norwegian Journal of Geology 59, 327336.

Holmsen, P., Padget, P. \& Pehkonen, E. 1957: The Precambrian geology of Vest-Finnmark, northern Norway. Geological Survey of Norway Bulletin 210, 107 pp.

Ihlen, P.M. \& Furuhaug, L. 2000: Gold resources on Ringvassøy, Troms III: Geochemistry of heavy mineral concentrates from stream sediments and potential gold sources. Geological Survey of Norway Report 2000.059, 104 pp.

Jones, R.R., Tanner, G.P.W. 1995: Strain partitioning in transpression zones. Journal of Structural Geology 17, 793-802.

Jones, R.R., Holdsworth, R.E., Clegg, P., McCaffrey, K. \& Tavarnelli, E. 2004: Inclined transpression. Journal of Structural Geology 26, 1531-1548.

Kjøll, H.J., Viola, G., Menegon, L. \& Sørensen, B.E. 2015: Brittle-viscous deformation of vein quartz under fluid-rich low greenschist facies conditions. Solid Earth 6, 681-669.

Koistinen, T. 1981: Structural evolution of an early Proterozoic stratabound $\mathrm{Cu}-\mathrm{Co}-\mathrm{Zn}$ deposit, Outokumpu, Finland. Transactions of the Royal Society of Edinburgh 72, 115-158.

Koistinen, T., Stephens, M.B., Bogatchev, V., Nordgulen, Ø., Wennerström , M., Korhonen, J. (compilers) (2001) Geological map of the Fennoscandian Shield, scale 1:2 000 000. Espoo, Geological Survey of Finland; Geological Survey of Norway, Trondheim; Geological Survey of Sweden, Uppsala; Ministry of Natural Resources of Russia, Moscow.

Korja, A., Lahtinen, R. \& Nironen, M. 2006: The Svecofennian orogen: a collage of microcontinents and island arcs. Geological Society London Memoirs 32, 561-578.

Krill, A.G. 1985: Svecokarelian thrusting with thermal inversion in the Karasjok- Levajok area of the northern Baltic Shield. Geological Survey of Norway Bulletin 403, 89-101.

Krill, A.G., Bergh, S.G., Lindahl, I., Mearns, E.W., Often, M., Olerud, S., Olesen, O., Sandstad, J.S., Siedlecka, A. \& Solli, A. 1985: Rb-Sr, U-Pb and Sm-Nd Isotopic Dates from Precambrian Rocks of Finnmark. Geological Survey of Norway Bulletin 403, 37-54.

Lahtinen, R., Garde, A. \& Melezhik, V.A. 2008: Palaeoproterozoic evolution of Fennoscandia and Greenland. Episodes 31, 20-28.

Lahtinen, R., Hölttä, P., Kontinen, A., Niiranen, T., Nironen, M., Saalmann, K. \& Sorjonen-Ward, P. 2011: Tectonic and metallogenic evolution of the Fennoscandian shield: key questions with emphasis on Finland. Geological Survey of Finland Special Paper 49, 23-33.

Lahtinen, R., Johnston, S.T. \& Nironen, M. 2014: The Bothnian coupled oroclines of the Svecofennian Orogen: a Palaeoproterozoic terrane wreck. Terra Nova 26, 330-335. 
Lahtinen, R., Huhma, H., Lahayea, Y., Jonsson, E., Manninen, T., Lauri, L.S., Bergman, S., Hellström, F., Niiranen, T. \& Nironen, M. 2015: New geochronological and Sm-Nd constraints across the Pajala shear zone of northern Fennoscandia: Reactivation of a Paleoproterozoic suture. Precambrian Research 256, 102-119.

Luth, S., Thörelöf, M., Berggren, R. \& Antal Lundin, I. 2014: Localization of dextral transpression along the KaresuandoArjeplog deformation zone, Akkiskera-Kuormakka area, northern Sweden. 31st Nordic Geological Winter Meeting, 8-10 January, Lund, Sweden, p. 56.

MacDonald, G.M. \& Goodenough, K.M. 2013: The South Barra shear zone: A composite Inverian-Laxfordian shear zone and possible Terrane boundary in the Lewisian gneiss complex of the Isle of Barra, NW Scotland. Scottish Journal of Geology 49, 93-103.

Marker, M. 1985: Early Proterozoic (ca. 2000-1900 Ma) crustal structure of the northeastern Baltic Shield; tectonic division and tectogenesis. Geological Survey of Norway Bulletin 403, 55-74.

Marker, M. 1988: Early Proterozoic thrusting of the Lapland Granulite Belt and its geotectonic evolution, northern Baltic Shield. Geologiska Föreningen i Stockholm Förhandlingar 110, 405-410.

McCourt, S. \& Vearncombe, J.R. 1992: Shear zones of the Limpopo Belt and adjacent granitoid-greenstone terranes: implications for late Archaean collision tectonics in southern Africa. Precambrian Research 55, 553-570.

Miller, H.G. \& Singh, V. 1994: Potential-field tilt - a new concept for location of potential-field sources. Journal of Applied Geophysics 32, 213-217.

Motuza, G., Motuza, V., Beliatsky, B. \& Savva, E. 2001: The Ringvassoya greenstone belt (Tromso, North Norway): implications for a Mesoarchaean subduction zone. EUROPROBE time-slice symposium and Proterozoic Plate Tectonics: Geological and Geophysical Records, 1 October-3 November, St. Petersburg, Russia, pp. 43-44.

Myhre, P.I., Corfu, F., Bergh, S.G. \& Kullerud, K. 2013: U-Pb geochronology along an Archean geotransect in the West Troms Basement Complex, North Norway. Norwegian Journal of Geology 93, 1-24.

Nasuti, A., Roberts, D. \& Gernigon, L. 2015: Multiphase mafic dykes in the Caledonides of northern Finnmark revealed by a new highresolution aeromagnetic dataset. Norwegian Journal of Geology 95, 285-297. http://dx.doi.org/10.17850/njg95-3-02.

Nilsen, K.S. \& Bjørlykke, A. 1991: Geological setting of the Bidjovagge gold-copper deposit, Finnmark, northern Norway. Geologiska Föreningen i Stockholm Förhandlingar 113, 60-61.

Nironen, M. 1997: The Svecofennian Orogen: a tectonic model. Precambrian Research 86, 21-44.

Novatem 2012: Fixed wing magnetic and radiometric survey of the coastal area of Northwestern Norway (FRASE). Novatem Airborne Geophysics Report, Mont-Saint Hilaire, Quebec, Canada, 36 pp.

Novatem 2014: Fixed wing magnetic and radiometric survey over the Troms-Finnmark region in Northern Norway (TROFI-14 East). Novatem Airborne Geophysics Report, Mont-Saint Hilaire, Quebec, Canada, 29 pp.

Often, M. 1985: The Early Proterozoic Karasjok Greenstone belt, Norway: A preliminary description of lithology, stratigraphy and mineralization. Geological Survey of Norway Bulletin 403, 75-88.

Ojala, J. 2007: Gold in Central Lapland Greenstone Belt. Geological Survey of Finland Special Paper 44, 225-250.

Olesen, O. \& Solli, A. 1985: Geophysical and geological interpretation regional structures within the Precambrian Kautokeino Greenstone Belt, Finnmark, North Norway. Geological Survey of Norway Bulletin 403, 119-133.

Olesen, O. \& Sandstad, J.S. 1993: Interpretation of the Proterozoic Kautokeino Greenstone Belt, Finnmark, Norway from combined geophysical and geological data. Geological Survey of Norway Bulletin 425, 43-64.

Olesen, O., Roberts, D., Henkel, H., Lile, O.B. \& Torsvik, T.H. 1990: Aeromagnetic and gravimetric interpretation of regional structural features in the Caledonides of West Finnmark and North Troms, northern Norway. Geological Survey of Norway Bulletin 419, 1-24.

Olesen, O., Henkel, H., Lile, O.B., Mauring, E. \& Rønning, J.S. 1992: Geophysical investigations of the Stuoragurra postglacial fault, Finnmark, northern Norway. Journal of Applied Geophysics 29, 95-118.

Olesen, O., Ebbing, J., Gellein, J., Gernigon, L., Koziel, J., Lauritsen, T., Mykelbust, R., Pascal, C., Sand, M., Solheim, A. \& Usov, S. 2010: New aeromagnetic and gravity compilations from Norway and adjacent areas - methods and applications. In Vining, B.A. \& Pickering, S.C. (eds.): Petroleum geology: from mature basins to new frontiers, Geological Society London, pp. 559-586

Park, R.G. 2005: The Lewisian terrane model: a review. Scottish Journal of Geology 41, 105-118.

Park, R.G., Tarney, J. \& Connelly, J.N. 2001: The Loch Maree Group: Palaeoproterozoic subduction-accretion complex in the Lewisian of NW Scotland. Precambrian Research 105, 205-226.

Passchier, C.W. \& Trouw, R.A.J. 1996: Microtectonics. Springer, Berlin, $366 \mathrm{pp}$.

Patison, N.J. 2007: Structural controls on gold mineralisation in the Central Lapland Greenstone Belt. Geological Survey of Finland Special Paper 44, 105-122.

Ramsay, J.G. 1980: Shear zone geometry: A review. Journal of Structural Geology 2, 83-89.

Robert, F. \& Brown, A.C. 1986: Archean gold-bearing quartz veins at the Sigma Mine, Abitibi greenstone belt, Quebec; Part I, Geologic relations and formation of the vein system. Economic Geology 81, 578-592.

Roberts, N.M.W., Slagstad, T. \& Viola, G. 2015: The structural, metamorphic and magmatic evolution of Mesoproterozoic orogens. Precambrian Research 265, 1-9.

Rodionov, A., Ofstad, F., Lynum, R. \& Tassis, G. 2012: Helicopter-borne magnetic, electromagnetic and radiometric geophysical survey in the Alta - Kvænangen area, Troms and Finnmark. Geological Survey of Norway Report 2012.065, 28 pp.

Saalmann, K. \& Niiranen, T. 2010: Hydrothermal alteration and structural control on gold deposition in the Hanhimaa shear zone and western part of the Sirkka Line. Geological Survey of Finland Report, M19/2741/2010/58, 30 pp.

Saalmann, K., Mänttäri, I., Ruffet, G. \& Whitehouse, M.J. 2009: Age and tectonic framework of structurally controlled Palaeoproterozoic gold mineralization in the Häme belt of southern Finland. Precambrian Research 174, 53-77.

Sanderson, D.J. \& Marchini, W.R.D. 1984: Transpression. Journal of Structural Geology 6, 449-458.

Sandstad, J.S. \& Nilsson, L.P. 1998: Gullundersøkelser på Ringvassøya; sammenstilling av tidligere prospektering og feltbefaring i 1997. Geological Survey of Norway Report 9807, p. 61 (in Norwegian).

Scheiber, T., Viola, G., Bingen, B., Peters, M. \& Solli, A. 2015: Multiple reactivation and strain localization along a Proterozoic orogenscale deformation zone: the Kongsberg-Telemark boundary of southern Norway revisited. Precambrian Research 265, 78-103.

Shackelton, R.M. 1995: Tectonic evolution of greenstone belts. Geological Society London Special Publication 95, 53-65.

Siedlecka, A., Iversen, E., Krill, A.G., Lieungh, B., Often, M., Sandstad, J.S. \& Solli, A. 1985: Lithostratigraphy and correlation of the Archean and Early Proterozoic rocks of Finnmarksvidda and the Sorvaranger district. Geological Survey of Norway Bulletin 403, $7-36$

Simpson, C. \& De Paor, D.G. 1993: Strain and kinematic analysis in general shear zones. Journal of Structural Geology 15, 1-20.

Solli, A. 1983: Precambrian Stratigraphy in the Masi Area, Southwestern Finnmark, Norway. NGU Bulletin 380, 97-105.

Stern, R.J. 2005: Evidence from ophiolites, blueschists, and ultrahighpressure metamorphic terranes that the modern episode of subduction tectonics began in Neoproterozoic time. Geology 33, 557-560.

Tavarnelli, E. 1997: Structural evolution of a foreland fold-and-thrust belt: the Umbria-Marche Apennines, Italy. Journal of Structural 
Geology 19, 523-534.

Tavarnelli, E., Holdsworth, R.E., Clegg, P., Jones, R.R. \& McCaffrey, K.J.W. 2004: The anatomy and evolution of a transpressional imbricate zone, Southern Uplands, Scotland. Journal of Structural Geology 26, 1341-1360.

Thébauda, N. \& Reyb, P.F. 2013: Archean gravity-driven tectonics on hot and flooded continents: Controls on long-lived mineralised hydrothermal systems away from continental margins. Precambrian Research 229, 93-104.

Torgersen, E., Viola, G., Sandstad, J.S. \& Smeplass, H. 2013: Structurally controlled copper mineralizations in the Paleoproterozoic Repparfjord Tectonic Window, Northern Norway. European Geosciences Union General Assembly 2013, 7-12 April, Vienna, Austria, EGU2013-4566.

Torgersen, E., Viola, G., Sandstad, J.S., Stein, H., Zwingmann, H. \& Hannah, J., 2015a: Effects of frictional-viscous oscillations on the structural evolution and re-Os pyrite-chalcopyrite systematics of $\mathrm{Cu}$-rich carbonate veins in northern Norway. Tectonophysics, 659, 70-90.

Torgersen, E., Viola, G. \& Sandstad, J.S., 2015b: Revised structure and stratigraphy of the northwestern Repparfjord Tectonic Window, northern Norway. Norwegian Journal of Geology 95, 397-421. http://dx.doi.org/10.17850/njg95-3-06.

Torske, T. 1977: A palæorift in the Precambrian of western Finnmark? Nytt fra Oslofeltgruppen 6,63 pp.

Torske, T. \& Bergh, S.G. 2004: The Čaravarri Formation of the Kautokeino Greenstone Belt, Finnmark, North Norway; a Palaeoproterozoic foreland basin succession. Geological Survey of Norway Bulletin 442, 5-22.

Van Kranendonk, M.J., Collins, W.J., Hickman, A. \& Pawley, M.J. 2004: Critical tests of vertical vs. horizontal tectonic models for the Archaean East Pilbara Granite-Greenstone Terrane, Pilbara Craton, Western Australia. Precambrian Research 131, 173-211.

Vearncombe, J.R. 1998: Shear zones, fault networks, and Archean gold. Geology 26, 855-858.

Vearncombe, J.R. \& Zelic, M. 2015: Structural paradigms for gold: do they help us find and mine? Applied Earth Science 124, 2-19.

Verduzco, B., Fairhead, J.D. \& MacKenzie, C. 2004: New insights into magnetic derivatives from structural mapping. The Leading Edge 23, 116-119.

Vidal, M., Gumiaux, C., Cagnard, F., Pouclet, A., Ouattara, G. \& Pichon, M. 2009: Evolution of a Paleoproterozoic "weak type" orogeny in the West African Craton (Ivory Coast). Tectonophysics 477, 145-159.

Viola, G. \& Henderson, I.H.C. 2010: Inclined transpression at the toe of an arcuate thrust: an example orogen from the Precambrian 'Mylonite Zone' of the Sveconorwegian Continental Tectonics and Mountain Building: The Legacy of Peach and Horne. Geological Society London Special Publications 335, 715-737.

Viola, G., Mancktelow, N. \& Miller, J. 2006: Cyclic frictional-viscous slip oscillations along the base of an advancing nappe complex: Insights into brittle-ductile nappe emplacement mechanisms from the Naukluft Nappe Complex, Central Namibia. Tectonics 25, TC3016. doi: 10.1029/2005TC001939.

Viola, G., Henderson, I.H.C., Bingen, B., Thomas, R., Smethurst, M.A. \& De Azavedo, S. 2008a: Growth and collapse of a deeply eroded orogen: Insights from structural, geophysical and geochronological constraints on the Pan-African evolution of NE Mozambique. Tectonics 27, TC5009. doi: 10.1029/2008TC002284.

Viola, G., Sandstad, J.S., Nilsson, L.P. \& Heincke, B. 2008b: Structural and ore geological studies in the Northwest part of the Repparfjord window, Kvalsund, Finnmark, Norway. Geological Survey of Norway Report 2008.029, 93 pp.

Ward, P., Härkönen, I., Nurmi, P.A. \& Pankka, H.S. 1989: Structural studies in the Lapland greenstone belt, northern Finland and their application to gold mineralization. Geological Survey Finland Special Paper 10, 71-77.

Weihed, P., Arndt, N., Billström, K., Duchesne, J.-C., Eilu, P., Martinsson, O., Papunen, H. \& Lahtinen, R. 2005: Precambrian geodynamics and ore formation: The Fennoscandian Shield. Ore Geology Reviews 27, 273-322.

Wikström, A., Skiöld, T. \& Öhlander, B. 1996: The relationships between $1.88 \mathrm{Ga}$ old magmatism and the Baltic-Bothnian shear zone in northern Sweden. In Brewer, T.S. (ed.): Precambrian Crustal Evolution in the North Atlantic Region, Geological Society London Special Publication 112, pp. 249-259.

Zhao, G., Cawood, P.A., Wilde, S.A. \& Sun, M. 2002: Review of global 2.1-1.8 Ga orogens: implications for a pre-Rodinia supercontinent. Earth Science Reviews 59, 125-162.

Zwaan, K.B. 1995: Geology of the Precambrian West Troms Basement Complex, northern Norway, with special emphasis on the Senja Shear Belt: a preliminary account. Geological Survey of Norway Bulletin 427, 33-36. 
